\title{
Reports
}

\section{COASTAL ENVIRONMENTS OF THE MARITIME PROVINCES}

\author{
E.H. OWENS \\ Coastal Studies Institute, Louisiana State University \\ Baton Rouge, Louisiana 70803 \\ A.J. BOWEN \\ Department of Oceanography, Dalhousie University \\ Halifax, Nova Scotia, B3H $4 \mathrm{~J} 1$
}

\begin{abstract}
This review of the coastal process and morphology characteristics of the Maritime Provinces provides a general summary of existing information and data for an area that has a wide variety of shoreline types, geologic units, and oceanographic conditions. The general coastal trends of the area are controlied by the regional southwesterly-northeasterly trending structures associated with the Appalachian system. Superimposed on this basic geologic fromework, the contrasting shoreline types result from the high degree of variability in local geology, relief, waveenergy levels, tidal range and sediment availability. This variability provides the basis for discussion of the shorelines of the Maritime Provinces. Twenty-two distinct coastal environments are systematically defined and described.
\end{abstract}

\section{INTRODUCTION}

The purpose of this paper is to provide a first approximation of the geomorphology and processes that characterize the coasts of the Maritime Provinces of Canada. The Maritime Provinces are a political region defined as the provinces of New Brunswick, Nova Scotia and Prince Edward Island and fall within the larger physiographic region of Atlantic Canada. The broad-scale characteristics of the. coastal zone of Atlantic Canada were discussed by Owens (1977a), who identified seven coastal environments (Fig. 1), and this paper presents a more detailed definition and description of the variations within those subdivisions of the southern Gulf of St. Lawrence, Atlantic Nova Scotia, the Bay of Fundy, and Sable Island that fall within the Maritime Provinces (Table 1). These coasts, which total $11,120 \mathrm{~km}$ of shoreline (Table 2), have a wide variety of shoreline types, but three distinct coastal environments can be distinguished: (1) the sheltered, wave-dominated coasts of the southern Gulf $(4717 \mathrm{~km}) ;(2)$ the exposed, high wave-energy Atlantic Ocean coasts $(4990 \mathrm{~km})$; and (3) the sheltered, tide-dominated coasts of the Bay of Fundy $(1413 \mathrm{~km})$. Within each of these three major coastal environments there is a great variation in the physical parameters (geology and geomorphology) and in the dynamic processes (oceanography). It is this variation that enables. further subdivision within each environmental unit.

This discussion is based on field observations in the southern Gulf of St. Lawrence (Owens and Harper 1972, Owens 1974a), in Nova Scotia (Bowen et $a$ I 1975, Owens 1971), and in the Bay of Fundy (Owens 1977b), on published work (e.g., Johnson 1925, Welsted 1974) and on an interpretation of topographic maps and aerial photography. Many sources of information and data at the regional and local scales have been consulted; the primary sources are included in the references and these should be examined for more specific data that cannot be included within the scope of this paper.

\section{COASTAL ENVIRONMENTS OF THE MARITIME PROVINCES}

The definition of coastal environments by progressive subdivision is based on the identification of geomorphic and process characteristics that provide each unit with some degree of homogeneity. clearly, as the units become smaller through subdivision the level of homogeneity increases. When defined as a single unit, Atlantic Canada is part of a trailing-edge coast of the American plate and is characterized by relatively low xelief and a wide continental shelf (Owens 1974a). This unit is part of the northern section of the Appalachian system and consists predominantly of deformed lower Paleozoic sedimentary rocks that were glaciated during the Pleistocene. This east-facing coast, on the North Atlantic Ocean, lies within a wave-climate region dominated by storm-generated waves (Davies 1964). These storms result from the west-to-east passage of cyclonic depressions along the southern edge of the polar continental air mass. During the cold winter months, sea ice forms in most parts of this unit, particularly in the Gulf of St. Lawrence (Owens 1976), in the Bay of Fundy and in sheltered areas along the Atlantic coast of Nova Scotia.

The Maritime coast of Atlantic Canada can be subdivided into four coastal environments: (1) The coast of the southerm Gulf of St. Lawrence is on the margin of an epicontinental sea, has low relief and a great variety of erosional and depositional features. This environment is wave-dominated and is characterized by microtidal conditions (range $<2 \mathrm{~m}$ ) (Table 3) in which sea ice Iimits wave action up to 4 months each year (Owens 1976). Not all of the subdivisions that were oxiginally identified in this unit (Owens and Harper 1972, Owens 1974a) are discussed here (Fig. 2, Table 4) as the Magdalen Islands and the Gaspe area are in Quebec, and the Baie des chaleurs is a river-dominated estuarine environment. (2) Atlantic Nova Scotia has a predominantly rocky shore zone of low relief on an open-ocean coast and is characterized by high wave-energy conditions. This unit has been subdivided into seven environments. (3) The Bay of Fundy is defined on the basis of tidal range alone $(>5 \mathrm{~m})$ and has been subdivided into six environments. (4) Sable Island is an isolated remnant depositional feature on the margin of the continental shelf, lying approximately $200 \mathrm{~km}$ offshore, and is a relatively small homogeneous unit that has not been further subdivided. 
TABLE 1

Characteristics of Maritime Provinces coastal Environments

\begin{tabular}{|c|c|c|c|c|c|c|c|}
\hline & Unit & $\begin{array}{l}\text { Geological } \\
\text { Character }\end{array}$ & $\begin{array}{l}\text { Backshore } \\
\text { Relief }\end{array}$ & $\begin{array}{c}\text { Beach } \\
\text { Character }\end{array}$ & $\begin{array}{c}\text { Fetch and } \\
\text { wave Exposure }\end{array}$ & $\begin{array}{c}\text { Mean Tidal } \\
\text { Range }\end{array}$ & $\begin{array}{c}\text { Sediment } \\
\text { Availability }\end{array}$ \\
\hline 4. & $\begin{array}{l}\text { Southern } \\
\text { Gulf of St. } \\
\text { Lawrence }\end{array}$ & $\begin{array}{l}\text { Predominantly un- } \\
\text { resistant Carboni- } \\
\text { ferous sedimentary } \\
\text { rocks with metasedi- } \\
\text { ments and igneous } \\
\text { rocks in eastern } \\
\text { areas: overlain by } \\
\text { thin till deposits. }\end{array}$ & $\begin{array}{l}\text { Low, unresistant } \\
\text { cliffs }(3-10 \mathrm{~m}) \text { with } \\
\text { cliffs up to } 100 \mathrm{~m} \\
\text { in eastern upland } \\
\text { areas }\end{array}$ & $\begin{array}{l}\text { Great variety, } \\
\text { ranging from barrier } \\
\text { islands to multiple } \\
\text { intertidal bars and } \\
\text { narrow beaches of re- } \\
\text { worked talus deposits }\end{array}$ & $\begin{array}{l}\text { Generally } \\
>300 \mathrm{~km} \text {, en- } \\
\text { closed sea. } \\
\text { Ice-free } \\
\text { season, 7-8 } \\
\text { months. }\end{array}$ & $1-2 m$ & $\begin{array}{l}\text { Generally } \\
\text { abundant }\end{array}$ \\
\hline 5. & $\begin{array}{l}\text { Atlantic } \\
\text { Nova Scotia }\end{array}$ & $\begin{array}{l}\text { Predominantly meta- } \\
\text { morphic and igenous } \\
\text { outcrops overlain } \\
\text { by till or drumlins }\end{array}$ & $\begin{array}{l}\text { Low, resistant } \\
\text { rocky shore zone } \\
\text { or cliffs (up to } \\
10 \mathrm{~m} \text { ) }\end{array}$ & $\begin{array}{l}\text { Absent or pocket } \\
\text { beaches; occasional } \\
\text { barrier beaches } \\
\text { and marshes. }\end{array}$ & $\begin{array}{l}\text { Open ocean } \\
\text { coast, very } \\
\text { exposed. Ice } \\
\text { only in shelter- } \\
\text { ed bays during } \\
\text { winter months. }\end{array}$ & $1-4 m$ & $\begin{array}{l}\text { Scarce or } \\
\text { very scarce }\end{array}$ \\
\hline & Bay of Fundy & $\begin{array}{l}\text { Resistant igenous } \\
\text { or unresistant sedi- } \\
\text { mentary rocks over- } \\
\text { lain by till or out- } \\
\text { wash. }\end{array}$ & $\begin{array}{l}\text { Generally rock } \\
\text { cliffs } \\
(5-200 \mathrm{~m})\end{array}$ & $\begin{array}{l}\text { Pebble-cobble: } \\
\text { wide sand or } \\
\text { mud tidal flats } \\
\text { in the upper bay. }\end{array}$ & $\begin{array}{l}\text { Generally } \\
<50 \mathrm{~km} \text {, shelter- } \\
\text { ed. Ice only in } \\
\text { sheltered areas } \\
\text { in winter. }\end{array}$ & $5-15 m$ & $\begin{array}{l}\text { Abundant in } \\
\text { upper bay, } \\
\text { elsewhere } \\
\text { very scarce. }\end{array}$ \\
\hline & Sable Island & Unconsolidated sand & Sand dunes & Wide, sandy beaches & $\begin{array}{l}\text { Open ocean coast, } \\
\text { very exposed. }\end{array}$ & $1 \mathrm{~m}$ & Abundant \\
\hline
\end{tabular}

(from Owens, 1977a) (see Fig. 1) 
THE SOUTHERN GULF OF ST. LANRENCE

The southern Gulf of St. Lawrence is a broad basin consisting of Permo-Carboniferous sandstones and shales that dipg gently to the northeast. This area of low relief is bounded on the northwest by the resistant Ordovician-Silurian rocks of the Gaspê and on the east by the pre-Carboniferous granitic and metamorphic uplands of western Cape Breton Island. At the regional level the major homogeneous elements are the low tidal range, a wave climate of locally generated storm waves, and the presence of sea ice for up to 4 months each winter. An important feature of wave-energy levels in this region is that wave height increases from west to east (Table 5). owing to the dominance of westerly winds in this epicontinental sea. Variations in the geomorphological and sedimentological characteristics of the coastal zone are controlled primarily by the local geology and physiography of the region. It is this variation that makes possible the further subdivision of the Maritime coast of the southern Gulf into eight units (Fig. 2, Table 4). These units represent four broad shoreline types: (1) resistant upland cliffed coasts; (2) low-lying unresistant sandstone cliff coasts, (3) barrier island system, and (4) the sheltered, mixed coastal environments of Nor thumberland Strait.

Northeast New Brunswick

The characteristics of northeastern New Brunswick have been treated in detail elsewhere (Owens 1974a, p. 63-71) and only a summary of that discussion is presented here. The geological formations that outcrop on the east coast of New Brunswick are flat-lying Carboniferous sandstones and shales (Fig. 3). These unresistant rocks dip seaward and have been gently folded along axes that are approximately perpendicular to the present coastline. A pre-glacial river system developed parallel to these structural trends. The post-glacial submergence of this drainage topography has produced a series of alternating headlands (Cape Richibucto, Point Escuminac, and Miscou Island) and embayments. (Kouchibouguac Bay, Miramichi Bay, and Baie des Chaleurs). The shore zone is backed by a wide, low coastal plain, and where Carboniferous rocks outcrop on the coast, cliffs rarely exceed $10 \mathrm{~m}$ in height. Offshore, gradients are low (Portage Island, Kouchibouguac Bay, Fig. 4) and bottom contours parallel the present shoreline.

On land the bedrock is mantled by thin ( 1 to $3 \mathrm{~m}$ ) deposits of red-brown gravel tills or fluvio-marine deposits, and extensive peat bogs up to $8 \mathrm{~m}$ thick are found in low-lying areas. Offshore the bedrock is covered by a thin veneer of gravelly sands derived from reworked pleistocene deposits and from the erosion of the unresistant Carboniferous rocks (Loring and Nota 1973). It is evident from mineralogical and sedimentological data that sand-sized sediments are being reworked, sorted, and transported by bottom currents at the present time. These sediments are transported into the shallow nearshore zone, where they are redistributed by tidal- and wave-induced currents (Owens 1975a). In addition to this onstiore transport, sediments are supplied to the littoral zone by erosion of coastal cliffs and by rivers. However, these latter sources are

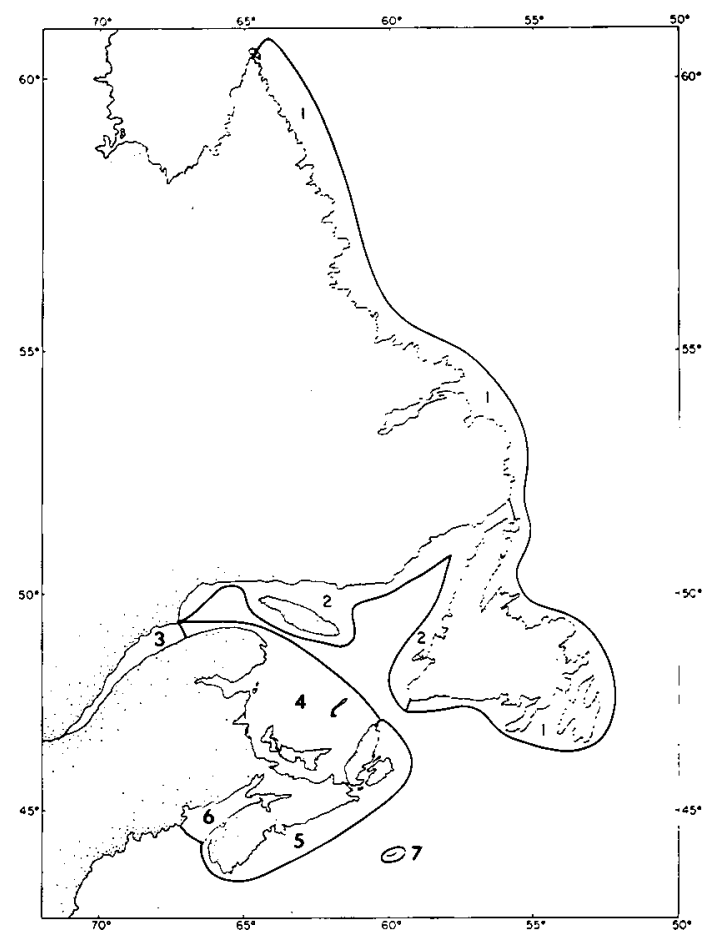

FIG. I Subdivision of Atlantic Canada into seven coastal environments (after Owens 1977a) (see also Table. 1). 1. Labrador and outer Newfoundland, 2. West Newfoundland - Northern Gulf of St. Lawrence, 3. St. Lawrence Estuary, 4. Southern Gulf of St. Lawrence, 5. Atlantic Nova Scotia, 6. Bay of Fundy, 7. Sable Island.

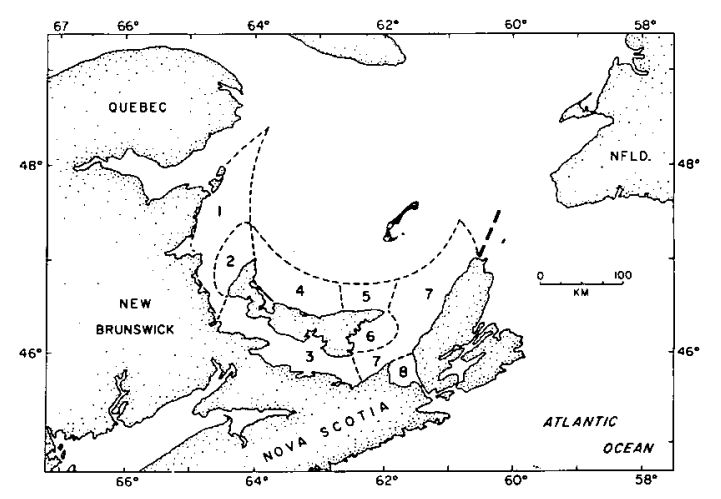

FIG. 2 Subdivisions of the southern Gulf of St. Lawrence (modified from Owens and Harper, 1972) (see Table 4).

1. Northeast New Brunswick, 2. West Prince Edward Island, 3. Northumberland Strait, 4. North Prince Edward Island, 5. Northeast Prince Edward Island, 6. East Prince Edward Island, 7. Antigonish - West Cape Breton Island, 8. St. Georges Bay. 
limited as a result of the short lengths of cliffed shoreline in this unit and the trapping of fluvial sediments in the drowned estuarine embayments. The development of extensive barrier island systems on this coast is attributed to the landward migration of intertidal and supratidal sediments during the postglacial transgression. The major contemporary source of littoral zone sediments is the adjacent seafloor, only a limited supply coming from coastal erosion and rivers (Owens 1974a).

The littoral zone sediments of this coast are predominantly in the sand-sized range, but local concentrations of pebble-cobble material are found adjacent to cliffed sections. Rates of cliff erosion are high (up to $3 \mathrm{~m} /$ year), but the outcrops of bedrock or Quaternary deposits are limited and the sandstone or shale coarse sediments are rapidly abraded by wave action or broken down by freezethaw in winter.

The rate of sea-level rise on this coast increases northward from the zero isobase south of Buctouche, to a maximum of 3 to $4 \mathrm{~m} / 1000$ years (Thomas et al, 1973). Evidence of a continuing slow rise in sea level is provided by the numerous outcrops of peat or lagoonal sediments in the intertidal zone of the barrier beaches.

The prevailing wind direction on this coast is offshore (Chatham: Fig. 5, Table 6); and, as the majority of waves in the southern Gulf are locally generated, this coast is in a relatively sheltered wave-energy environment (Gaspe and northwestern Prince Edward Island; Table 5). The characteristic feature of the process environment is the effects of storm-wave activity associated with the passage

TABLE 2

Maritime Provinces Coastline Measurements (in km)

A. New Brunswick

Gulf of St. Lawrence $(1,677)$

Bay of Fundy (608)

Prince Edward Island

1,260

Nova Scotia

Gulf of St. Lawrence $(1,780)$

Atlantic Coast $\quad(4,990)$

Bay of Fundy $\quad($ 805)

7,575

Total 11,120

B. Southern Gulf of St. Lawrence $\quad 4,717$ Atlantic Coast $\quad 4,920$

Bay of Fundy $\quad 1,413$

Sable Island

70

Tótal 11,120

(source: E.J. Cooper, Canadian Hydrographic Service, Ottawa, Personal Communication, 1971.) of cyclonic depressions across the area. The frequency and intensity of these low-pressure systems is greatest in winter and spring. Wave heights rarely exceed $5 \mathrm{~m}$ (Table 5), and Bryant and McCann (1972) noted that wave generation is limited by the predominance of offshore winds, the variability of the wind direction and the presence of sea ice during winter months. An ice foot is present on the beaches for minimum periods of 3 months each year, and sea ice, either as floes or close pack, is present for periods extending to 4 months each year (Owens 1976).

The mean tidal range in this subdivision is on the order of $1 \mathrm{~m}$ (Table 3 ). Tides are mixed or semi-diurnal, and a marked diurnal inequality occurs south of Richibucto. Storm surges are important in this microtidal environment and may cause local sea-level changes greater than those that result from the tides.

TABLE 3

Tide Characteristics

\begin{tabular}{|c|c|c|c|}
\hline \multirow{2}{*}{ Location } & \multirow{2}{*}{ Subdivision } & \multicolumn{2}{|c|}{ Range } \\
\hline & & $\begin{array}{l}\text { Mean } \\
\text { (m) }\end{array}$ & $\begin{array}{c}\text { Large } \\
(\mathrm{m})\end{array}$ \\
\hline
\end{tabular}

Southern Gulf of

St. Lawrence

$\begin{array}{llll}\text { Portage Island, NB } & 1 & 1.1 & 1.6 \\ \text { Miminegash, PEI } & 2 & 0.8 & 1.2 \\ \text { Charlottetown, PEI } & 3 & 1.8 & 2.9 \\ \text { Malpeque, PEI } & 4 & 0.8 & 1.1 \\ \text { North Lake, PEI } & 5 & 0.7 & 1.1 \\ \text { Georgetown, PEI } & 6 & 1.1 & 1.8 \\ \text { Margaree, NS } & 7 & 0.7 & 1.2 \\ \text { Auld Cove, NS } & 8 & 0.9 & 1.5\end{array}$

AtZantic Nova Scotia

Ingonish Ferr
North Sydney
Louisburg
Guysborough
Halifax
Yarmouth

$\begin{array}{ccc}1 & 0.9 & 1.4 \\ 2 & 0.9 & 1.4 \\ 3 & 1.2 & 1.7 \\ 4 / 5 & 1.4 & 2.0 \\ 6 & 1.4 & 2.1 \\ 7 & 3.7 & 5.1\end{array}$

Bay of Fundy

Digby, NS Advocate, NS Burncoat Head, NS

Pecks Point, NB

Saint John, NB

st. Andrews, NB

Sabie Island

$\begin{array}{rrr}1 & 6.8 & 9.3 \\ 2 & 9.1 & 12.6 \\ 3 & 11.9 & 16.0 \\ 4 & 10.2 & 14.4 \\ 5 & 6.7 & 9.1 \\ 6 & 6.0 & 8.3 \\ & 1.1 & 1.6\end{array}$

(source: Canadian Hydrographic Service, 1975a,b) 
Erosion of the unresistant coastal outcrops or the Quaternary deposits and sedimentation in the form of barxier-island development across the embayments have greatly simplified the trend of the coast. Sediment transport is generally north to south in response to waves generated by winds out of the northeast quadrant. Where headlands interrupt the generally straight coast (at Point Escuminac and Cape Richibucto), local reversals of this transport direction result (Fig. 6).

Barriers have developed on the northern part of this coast south of Miscou and Shippegan Islands (Fig. 7). On this coast the most southerly series of barriers have grown across the Miramichi embayment and are subject to rapid change by inlet migration and distal extension during storms (Owens 1974a, 1975a, Munroe 1976). These barrier beaches are generally low in height $(<3 \mathrm{~m}$ ). (Fig. 8) and are subject to frequent overwashduring storms. This section of coast is characterized by high rates of longshore transport as a result of the orientation of the shoreline with respect to waves out of the northeast. A similar system of barrier islands characterized by north-to-south longshore transport has developed south of Point Escuminac in Kouchibouguac Bay (Bryant 1972, Davidson-Arnott and Greenwood 1976). This shoreline is oriented more northeasterly, so that the angle of wave approach is less acute. This coastal orientation results in lower rates of longshore sediment transport, and in greater stability of the barriers and inlets. Also, the barrier systems are wider and the dunes are higher $(6 \mathrm{~m})$. South of Cape Richibucto a large flying spit has developed across the Buctouche embayment. The southerly migration of this barrier spit is indicated by the development of multiple recurved ridges in the distal section (Fig. 9).

\section{West Prince Edward Island}

Western Prince Edward Island is characterized by a relatively homogeneous, straight, rocky, cliffed coast of unresistant Permo-Carboniferous sandstones and shales. These rocks have been deformed along a broad structural axis that parallels the shoreline (Prest 1962). The uniformity of the coastal geomorphology is interrupted only by three stream exits

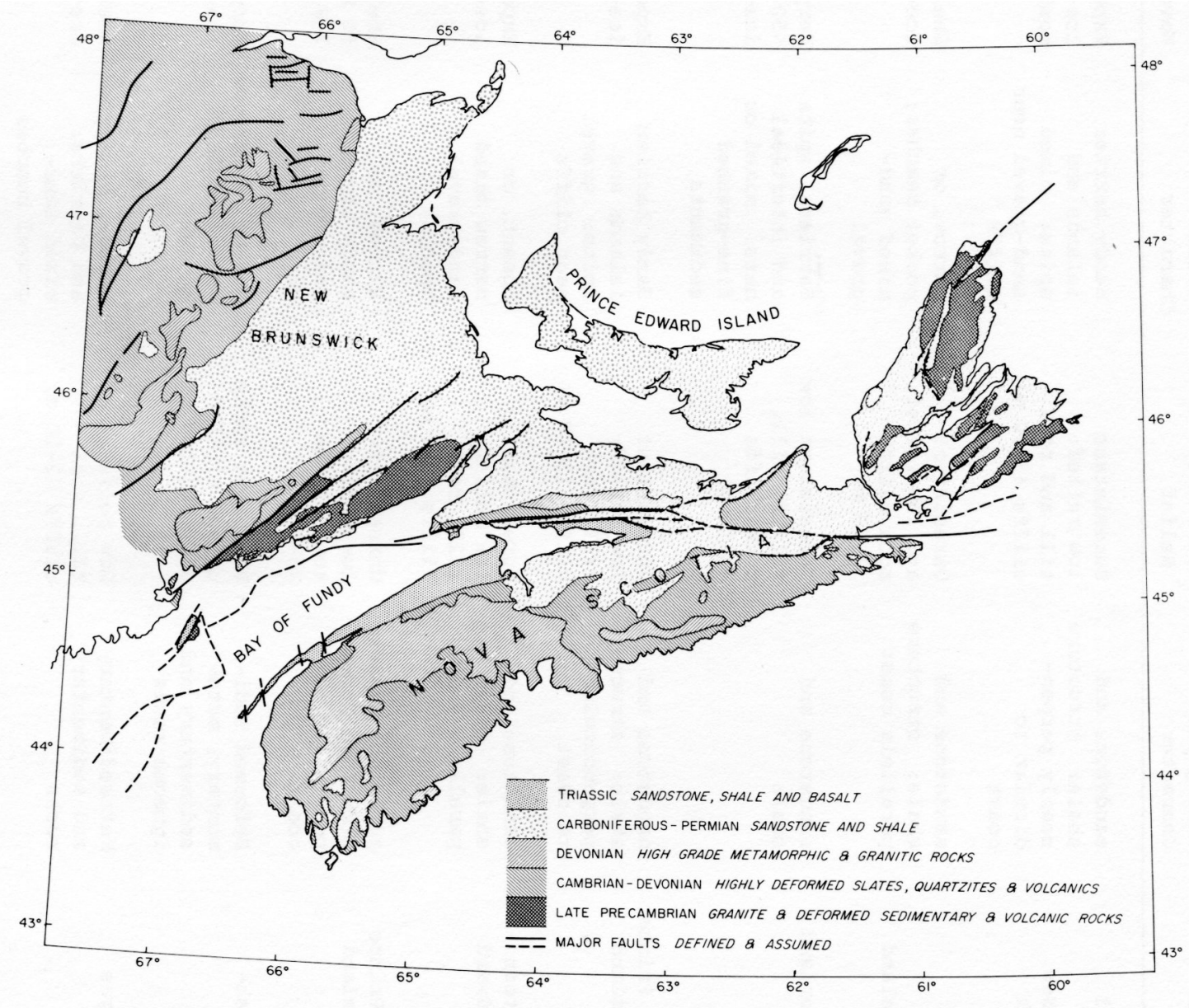

FIG. 3 Geology of the Maritime Provinces (compiled from various sources). 
Characteristics of the Coastal Environments of the Southern Gulf of St. Lawrence

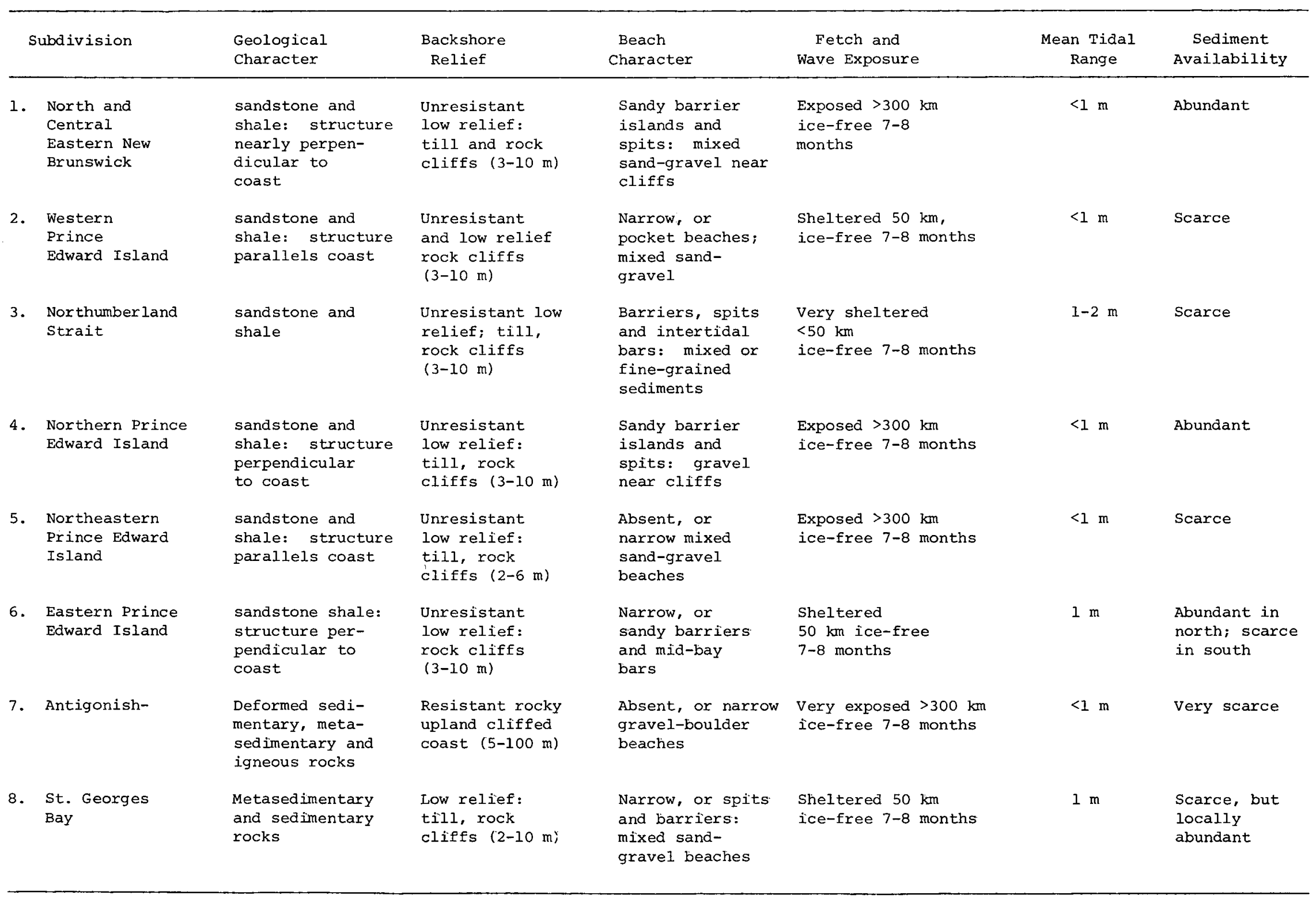

(see Fig. 2) (after Ownes and Harper, 1972) 

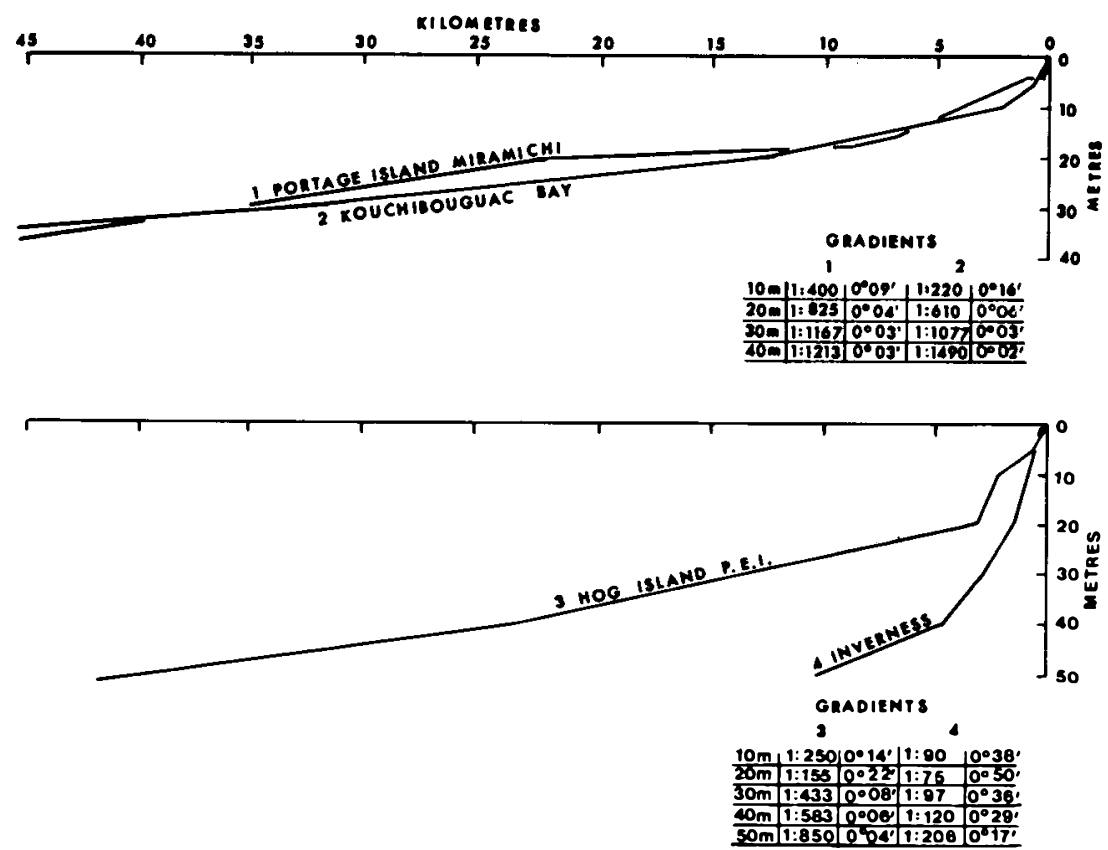

FIG. 4 Offshore profiles and gradients in the southern Gulf of St. Lawrence.

that discharge from the low-lying coastal plain. The bedrock is overlain by glacial or glacio-marine deposits of varying thickness (Prest 1973) that are exposed in coastal cliff sections. The cliffs are generally on the order of 5 to $10 \mathrm{~m}$ in height, reach a maximum of $20 \mathrm{~m}$, and occasionally produce stacks or arches.

Where present, the littoral zone sediments are reworked sand-pebble-cobble talus deposits derived from cliff erosion (Owens 1974b). Rates of erosion are high, and Prest (1973) reported that at North Point, where the outcrops comprise relatively resistant calcareous strata, the cliffs are $5 \mathrm{~m}$ high and eroded at an average rate of $0.67 \mathrm{~m} /$ year between 1935 and 1972. Beaches are absent or narrow except at Nail Pond, Skinners Pond and Miminegash, where small barriers with inlets have developed across valleys, and at the southern extremity of the subdivision (West Point), where a foreland is prograding to the south from the bedrock coast. At these four depositional locations the beach material is predominantly in the mediumsand size range.

This microtidal environment (Table 3) has a very short fetch (Maximum $75 \mathrm{~km}$ ). to the northwest. Waves generated across this fetch are of short period and low height, and the most important wave component is derived from waves out of the northern quadrant, which are refracted as they apprach the coast. The angle of incidentce of these refracted waves is high and, as a result, longshore currents are generated toward the south. The resulting north-to-south longshore sediment transport provides a limited volume of material for the development of West Point.

Northumberland Strait

The bedrock of Northumberland Strait comprises unresistant Upper Carboniferous and Permian sedi- mentary rocks that are horizontal or gently folded. In the western half of the unit, fold axes trend northeasterly-southwesterly, across the strait, whereas in eastern areas they are parallel or subparallel with the coast. The Strait was formed by pre-glacial erosion that separated the more resistant cuesta upland of Prince Edward Island from the area to the south (Johnson 1925). Kranck (1972a) delineated two major pre-Wisconsin river valley systems that flowed to the east and to the west, away from a drainage divide between Borden, Prince Edward Island, and Cape Tormentine, New Brunswick. The post-glacial submergence of this valley system has resulted in an irregular drowned coast along both shores of the Strait. Physiographically, the Strait is shallower west of the drainage divide ( 10 to $20 \mathrm{~m}$ ) than to the east $(>30 \mathrm{~m})$. At its widest the strait is $50 \mathrm{~km}$, but narrows to a minimum of $15 \mathrm{~km}$.

The surficial sediments of the Strait and the adjacent coastal zone are predominantly glacial drift deposits. There is considerable variation in both the texture and the thickness of these tills (Kranck 1971, Prest 1973). The bottom sediments of the Strait are being reworked and redistributed at the present time by the effects of residual tidal currents (Kranck 1972b). Erosion of the unresistant coastal cliffs and the unconsolidated Pleistocene deposits provides sediment directly to the littoral zone. Very little sediment is supplied to the coast by rivers owing to the small size of the drainage basins.

Sediments in the littoral zone are predominantly fine- or medium-grained sands, though there is considerable local variation (Owens 1974b). Rates of coastal erosion are high ( 1 to $2 \mathrm{~m} /$ years), but may reach a maximum of $4 \mathrm{~m}$ /year locally (Forward $1960 a$, b).

A detailed discussion of post-Pleistocene sea- 

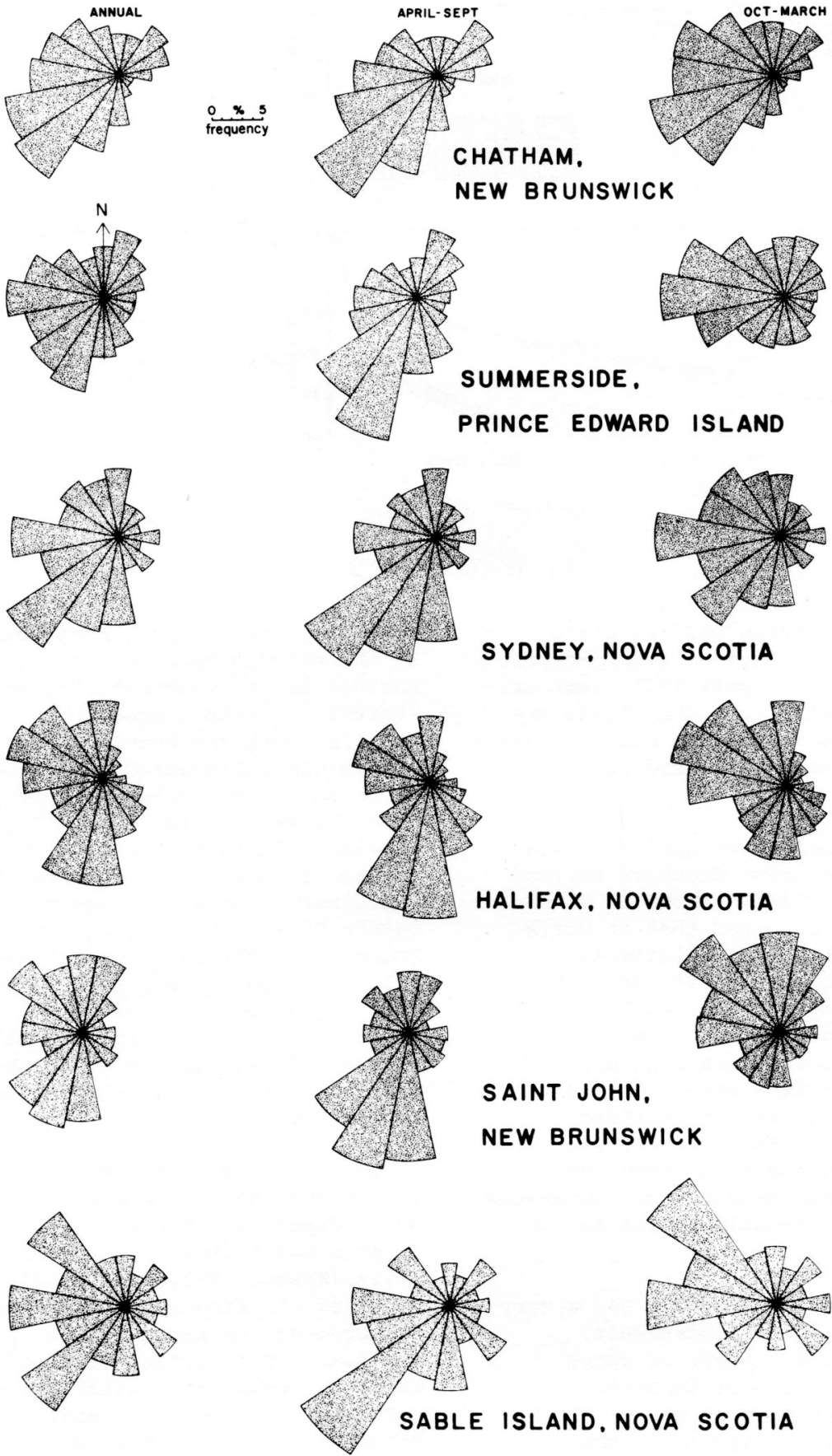

FIG. 5 Annual and Seasonal wind roses for selected stations (source: Canada Dept. of Transport, 1968) (see also Table 6). 


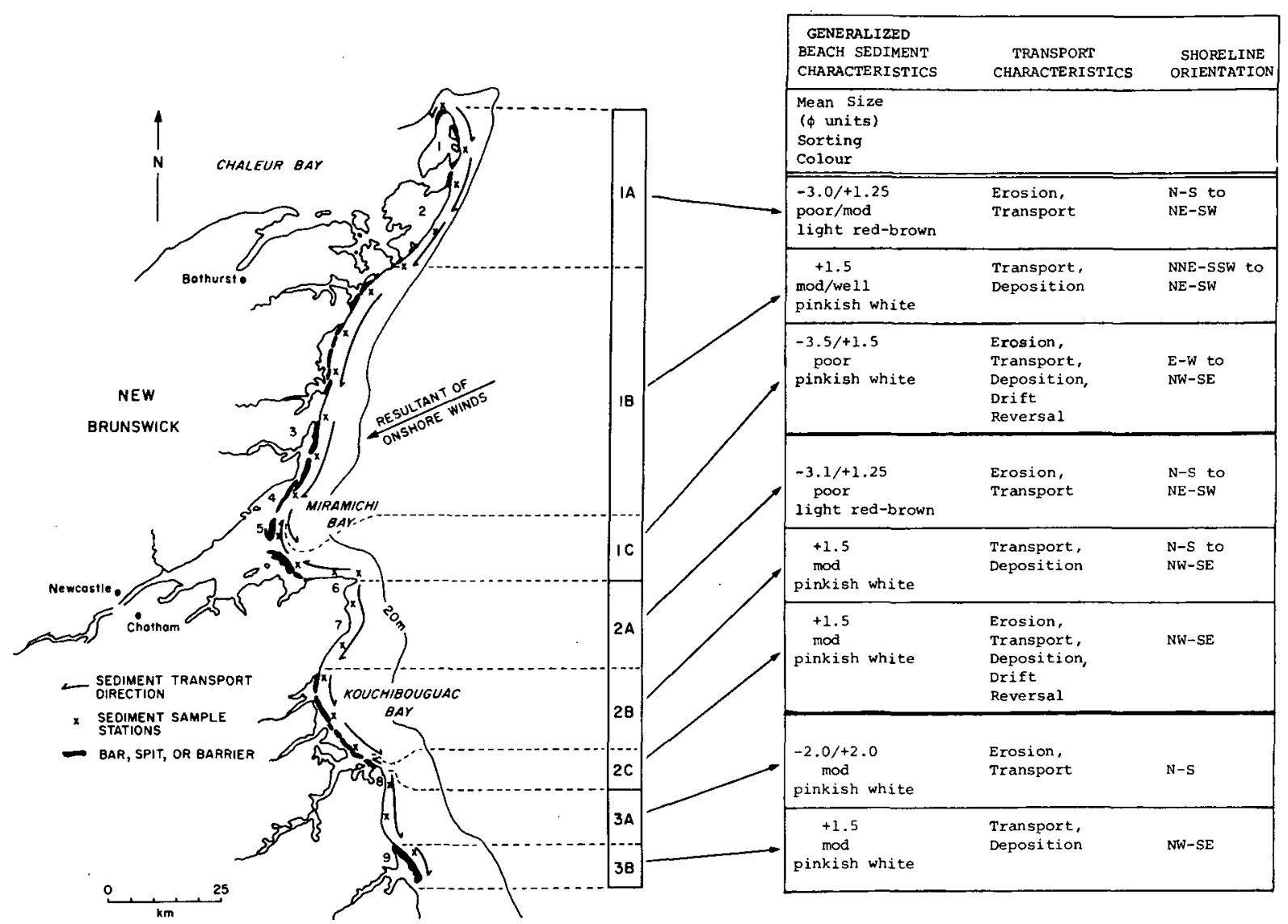

FIG. 6 Sediment dispersal pattern, northeastern New Brunswick (from Owens, 1974a).

1. Miscou Island, 2. Shippegan Island, 3. Tabusintac Lagoon, 4. Neguac Bar, 5. Portage Island, 6. Point Escuminac, 7. Point Sapin, 8. Cape Richibucto, 9. Buctouche Bar.

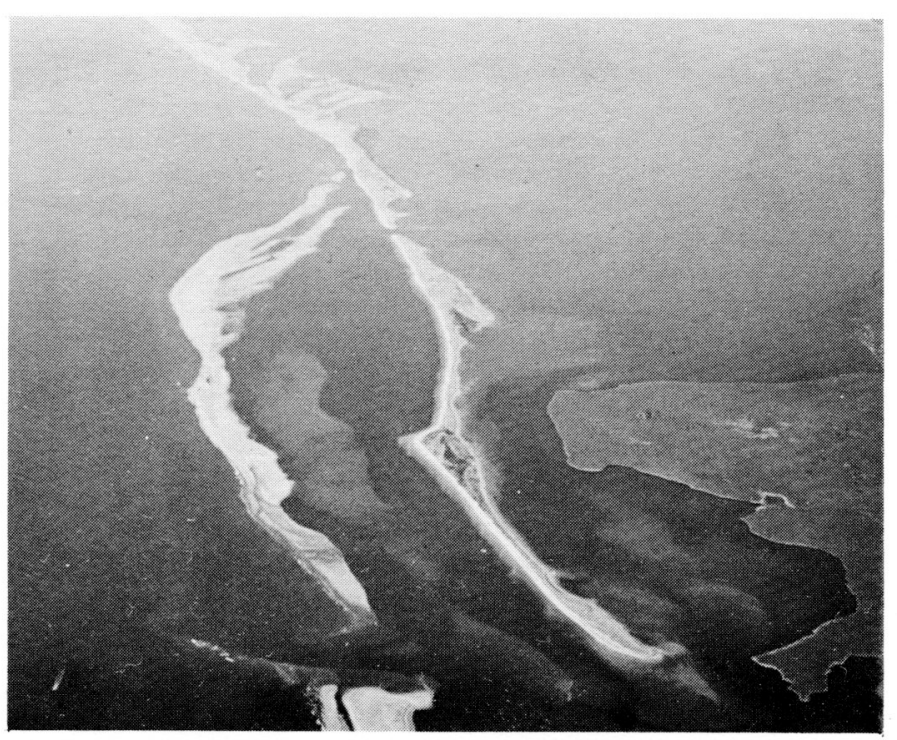

level changes in Northumberland Strait by Kranck (1972a) indicates that to the west of the drainage divide an initial marine overlap was followed by regression to about $-40 \mathrm{~m}$. Despite a positive crustal movement in this area, sea level continues to rise slowly (Kranck 1972a). In the eastern areas, the sea-level rise has always been greater than isostatic changes, and northumberland strait became a continuous body of water approximately 5000 years BP, when the drainage divide was breached (Kranck 1971). Sea level continues to rise throughout the region at a rate of approximately $3 \mathrm{~m} / 1000$ years.

The relatively high tidal ranges within this unit distinguish it from other coastal sections of the southern Gulf (Table 3). Fetches are very limited, so that the role of tides in littoral processes is proportionately increased. The largest predicted

FIG. 7 Overlapping borrier islands af Neguac, Miramichi Estuary N.B. These low barriers are migrating to the south (towards the top in this photograph). 
tides (Canadian Hydrographic Service 1975a) occur at Point Elgin, in Baie Verte, New Brunswick (mean tides $1.95 \mathrm{~m}$, large tides $2.93 \mathrm{~m}$ ). Kranck (1972b) correlated the distribution of bottom sediments and areas of erosion or deposition with tidalcurrent velocities. The effects of wave action vary considerably within the strait, depending on both exposure and aspect. Sheltered areas, such as Baie verte, are essentially tide-dominated, whereas exposed coasts (e.g., Egmont Bay) have considerable wave activity, higher rates of littoral sediment transport, and greater shoreline simplification. Winds out of the west or northwest can generate large waves down the axis of the strait, and winds from this quadrant prevail from October to March (Summerside: Fig. 5, Table 6). As in all areas of the southern Gulf, ice is an important limiting factor in wave generation from December to April.

Directions and rates of longshore sediment transport depend on local exposure to waves, although in general there is a west-to-east transport direction on both north and south coasts. The major characteristic of this unit of coast is the variety of landforms, which include wave-cut rock platforms and cliffs, intertidal bar sequences, and small barrier islands. This variety results from the configuration of the strait and from the sheltered nature of much of the coast. Relatively little shoreline simplification has occurred, and many of the embayments or drowned estuaries are independent cells of sediment transport. The predominant coastline features are low cliffs $(<10 \mathrm{~m})$. of unresistant bedrock or glacial deposits. Barrier beaches are usually limited in length and low in height. Forward (1960a) presented maps of shoreline changes in Egmont and Bedeque Bays, Prince Edward Island, that indicate significant rates of barrier island and spit migration in these exposed locations. In sheltered areas the intertidal rock platforms frequently are covered by a thin veneer of sediment that has been redistributed to form sequences of multiple linear bars (Fig. 10). Marshes are common in locations sheltered from direct wave activity.

North Prince Edward Island

The north. coast of Pxince Edward Island is oriented perpendicular to the structural trends except in. the extreme western and eastern sections. In the west the northeast-southwest fold axis: is parallel to the coast as a result of pre-glacial fluvial erosion that formed a cuesta ridge now expressed by the Tignish-North Point headland. In eastern areas the fold axes change from northeastsouthwest to west-east and give rise to a different geomorphological subdivision, which is treated separately below. A pre-glacial drainage system developed parallel with the northeast-southwest trending fold axes in the Permo-Carboniferous rocks. The subsequent post-glacial rise in relative sea level had drowned the estuaries, to produce a series of large, shallow embayments. The coast is characterized by barrier islands or bay-mouth bars that have developed across the embayments and by eroding headlands at the interfluves. Backshore relief is usually low and, although cliffs up to $30 \mathrm{~m}$ are present, coastal exposures are generally less than $10 \mathrm{~m}$. Offshore gradients are low (Hog Island:
Fig. 4) and the nearshore bottom contours to $20 \mathrm{~m}$ parallel the present coast.

The adjacent land areas have deposits of glacial, glacio-marine, and glacio-fluvial sediments (Prest 1973). A marine overlap that resulted from an initial post-glacial transgression is limited to areas west of Cape Tryon. This overlap was followed by a regression to $-40 \mathrm{~m}$ and a subsequent transgression. East of Cape Tryon the rise of sea level has always exceeded isostatic changes. The barrier beach deposits are derived largely from the reworking of glacial sediments and the landward migration of the barriers during the contemporary transgression. At the present time sand is supplied to the coastal zone from the erosion of coastal cliffs and from offshore. As noted above, Prest (1973) reported a rate of cliff erosion at North Point of $0.67 \mathrm{~m} /$ year between 1935 and 1972. In the vicinity of Cape Tryon the exosion rate of a section of Permo-Carboniferous outcrop, $28 \mathrm{~m} \mathrm{high,}$ has been estimated at approximately $1.5 \mathrm{~m} /$ year from a comparison by means of ground photography (Owens 1974a, Fig. 5). In addition to these local sources, material is supplied from the sea floor by reworking of offshore sediments and by redistribution toward the shallow nearshore zones (Owens 1975a).

The littoral sediments of the barrier beaches are predominantly in the fine- or medium-sand size ranges (Owens 1974b). Adjacent to cliffs these sands are mixed with pebble-cobble material derived from reworked talus deposits.

The tidal range in this unit is generally less than $1 \mathrm{~m}$ (Table 3 ), and this coast is dominated by wave-generated processes. This high-energy coast is exposed to waves from a direction between northwest and east. There is a seasonal variation in wave-energy levels (northwestern Prince Edward Island, Table 5) similar to that reported on the west coast of the Magdalen Islands (Owens 1977c). This seasonal effect is due to the greater frequency and intensity of low-pressure systems crossing the region during winter months. A direct result of the seasonal wave climate is the summer-wintex beach cycle, which is caused by erosion during fall and winter months and accretion in spring and summer.

In the western half of the unit, nearshore and littoral sediments are transported from north and northwest to the east. East of Cape Tryon, baymouth bars have developed across St. Peters Bay, Tracadie Bay, Rustico Bay, and New London Bay in response to sediment transport from east to wȩst at rates on the order of 160,000 to $250,000 \mathrm{~m}^{3} /$ year (Armon 1975). This drift reversal is due probably to the relatively deeper water off eastern areas, which permits waves out of the northwest and north to approach the coast more closely before refraction commences.

Shoreline simplification has produced a relatively straight coast in this unit. All the embayments have been enclosed by barrier beaches to give lagoonal or estuarine environments. Dunes on these barriers are up to $15 \mathrm{~m} \mathrm{high} \mathrm{(Fig.} \mathrm{11),} \mathrm{and} \mathrm{the} \mathrm{stable}$ barriers are not subject to rapid changes in plan form (McCann 1972); but inlet development and closure 
FIG. 8 Ground view of low barrier island near Neguac, N.B. The dune ridge is less than $\mathrm{lm}$ in height.

FIG. 9 Distal section of the flying spit at Buctouche, N.B., showing recurved ridges and alongshore movement of liftoral sediments as a series of migrating sand lenses in the intertidal zone.

FIG. 10 Intertidal sand bars on a wave-cut platform, Hillsborough Bay, southern P.E.I. Erosion of the unresistant Permo-Carboniferous sandstones provides a local source for the multiple linear bars.
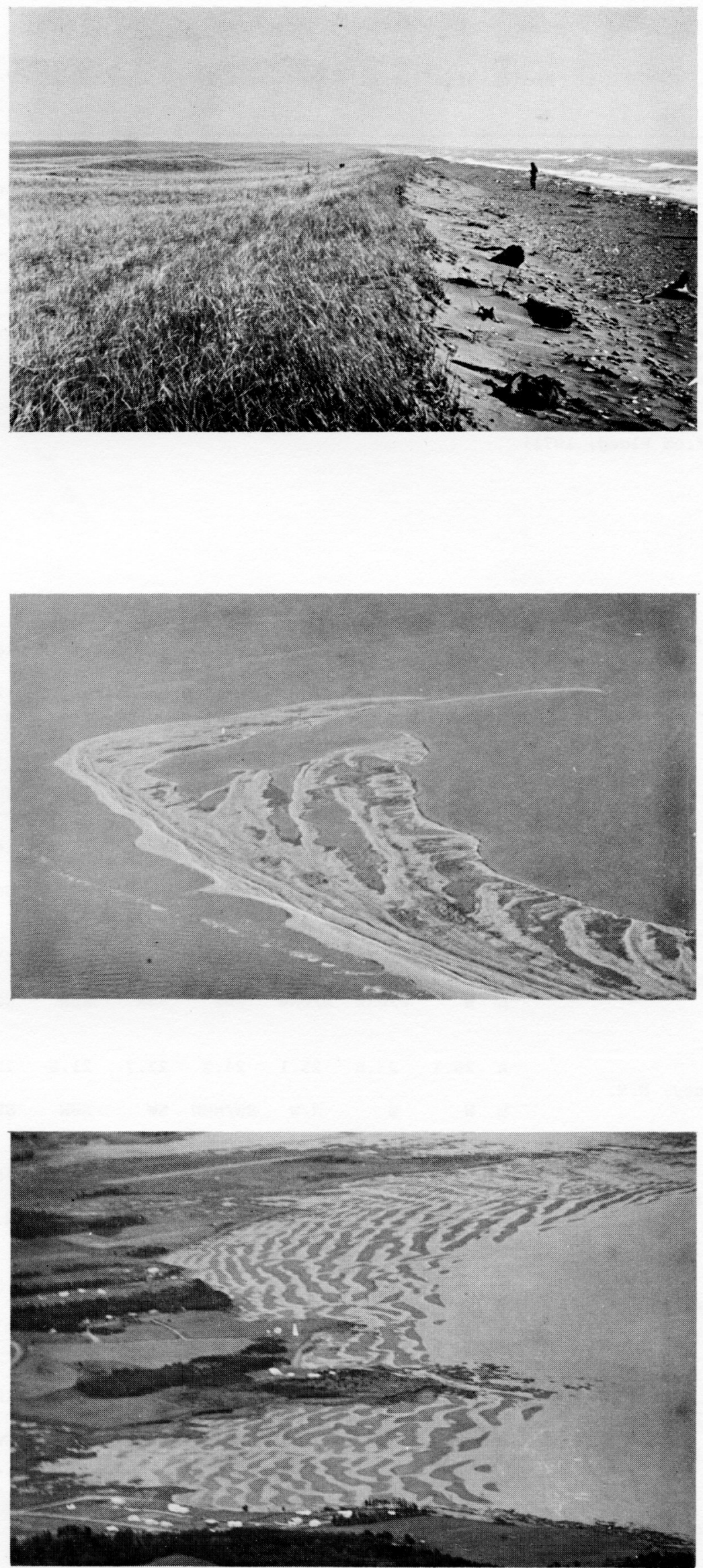
TABLE 5

Median Significant Wave Height in Southern Gulf of St. Lawrence 1967 (m)

\begin{tabular}{|c|c|c|c|c|c|}
\hline & $\begin{array}{c}\text { June to } \\
\text { Mid September }\end{array}$ & $\begin{array}{l}\text { Mid September } \\
\text { to October }\end{array}$ & $\begin{array}{l}\text { November - } \\
\text { December }\end{array}$ & $\begin{array}{l}\text { Whole } \\
\text { Season }\end{array}$ & $\begin{array}{l}\text { Expected } \\
\text { Significant } \\
\text { Wave Height } \\
\text { Once/Year }\end{array}$ \\
\hline Gaspé & 0.6 & 0.9 & 0.8 & 0.8 & 6.4 \\
\hline NW Prince Edward Island & 0.6 & 1.0 & 1.1 & 0.9 & 5.5 \\
\hline NE Prince Edward Island & 0.8 & 1.0 & 1.3 & 0.9 & 5.8 \\
\hline N Magdalen Islands & 1.1 & 1.5 & 1.9 & 1.4 & 7.6 \\
\hline N Cape Breton Island & 1.2 & 1.7 & 3.2 & 1.4 & 7.6 \\
\hline
\end{tabular}

(from Ploeg, 1971)

TABLE 6

Monthly Wind Data From Selected Stations

a. Mean wind velocity $(\mathrm{km} / \mathrm{hr})$

b. Prevailing wind direction

\begin{tabular}{|c|c|c|c|c|c|c|c|c|c|c|c|c|c|}
\hline & & & & & & & & & & & & & \\
\hline & & Jan & Feb & Mar & Apr & May & Jun & JuI & Aug & sep & oct & Nov & Dec \\
\hline & $a$ & 16.7 & 16.4 & 17.4 & 16.3 & 16.1 & 16.4 & 14.6 & 14.2 & 15.0 & 15.6 & 15.6 & 15.6 \\
\hline & $\mathrm{b}$ & WSW & WSW & WNW & $\mathrm{NE}$ & SW & SW & SW & SW & SW & SW & WSW & WSW \\
\hline & $a$ & 28.2 & 26.4 & 27.4 & 24.8 & 24.1 & 24.3 & 21.7 & 22.2 & 24.0 & 24.0 & 26.2 & 26.7 \\
\hline & $\mathrm{b}$ & $\mathrm{W}$ & W/WNW & $\mathrm{N} / \mathrm{WNW}$ & NNE & SSW & SSW & SSW & SSW & sSW & W & w & w \\
\hline & $a$ & 26.1 & 25.6 & 25.1 & 24.2 & 22.7 & 21.8 & 20.9 & 20.4 & 21.5 & 22.8 & 23.8 & 24.6 \\
\hline & $\mathrm{b}$ & $\mathrm{W}$ & w & $\mathrm{N} / \mathrm{W}$ & $\mathrm{SW} / \mathrm{NNW}$ & sw & SSW & SW & SW & SW & SW & $\mathrm{SW} / \mathrm{N}$ & SW \\
\hline & $a$ & 20.4 & 19.2 & 20.8 & 18.7 & 17.5 & 16.7 & 15.1 & 15.3 & 15.4 & 17.3 & 18.5 & 19.5 \\
\hline (1) & $\mathrm{b}$ & WNW & WNW & WNW & $\mathrm{N} / \mathrm{NW}$ & $\mathrm{s}$ & $\mathrm{s}$ & $\mathrm{s}$ & S/SSW & SSW & S/SSW & NW & NW \\
\hline & $\mathrm{a}$ & 21.1 & 19.8 & 21.1 & 18.7 & 18.0 & 17.7 & 15.4 & 15.1 & 16.1 & 18.3 & 20.1 & 20.0 \\
\hline - & $b$ & $\mathbf{N}$ & NW & NW & NNE & SSW & SSW & $s$ & S/SSW & SSW & $\mathrm{SW} / \mathrm{NW}$ & NW & NW \\
\hline & $a$ & 32.5 & 31.1 & 30.1 & 26.5 & 22.8 & 19.8 & 18.3 & 18.6 & 21.8 & 25.1 & 28.5 & 30.7 \\
\hline 年 & $\mathrm{b}$ & NW & NW & NW & NW & SW & SW & SW & SW & SW & W & NW & NW \\
\hline
\end{tabular}


occur aperiodically (Armon 1975).

Northeast Prince Edward Island

Along northeastern Prince Edward Island (50 km), between Cable Head and East Point, is a straight section of cliffed coastline which includes only five small depositional areas. The coast is subparallel to a series of minor cuestas in the unresistant Permo-Carboniferous bedrock that trend $\mathrm{N} 90^{\circ} \mathrm{W}$ to $\mathrm{N} 60^{\circ} \mathrm{W}$ (Crowl 1969). Surficial deposits of.tills, moraines, and kame or outwash sediments (Prest 1973) up to $3 \mathrm{~m}$ thick mantle the coastal bedrock exposures. Cliff heights range between 2 and $6 \mathrm{~m}$, and variations in the generally straight, flat-topped cliffs result from local changes in lithology and topography.

The intertidal zone is chaxacterized by rock platforms which, in parts, are mantled by a thin veneer of sediments that range in size from sands to boulders. No data are available on rates of erosion, but it is expected that these are on the same order ( 1 to $2 \mathrm{~m} /$ year) as reported elsewhere on this north-facing coast. Small beach deposits occur at Naufrage, Big Pond, Bayfield, North Lake, and East Lake, where stream valleys interrupt the cliffed coast.

This coast is a relatively high-energy environment as it is exposed to all waves generated in the northern sector between west and east. The prevailing direction of wave approach is out of the west-northwest, and a strong west-to-east littoral drift direction is predominant. As the coast comprises predominantly bedrock outcrops with few irregularities, sediments are transported through the unit toward and beyond East Point.

\section{East Prince Edward Island}

The coast of eastern Prince Edward Island is characterized by a large number of drowned valleys, few of which have been enclosed by barriers or baymouth bars. The pre-glacial drainage system developed on the Permo-Carboniferous bedrock along shallow est-east fold axes that are perpendicular to the present shoreline trend. The post-glacial rise in sea level caused inundation of the lowlying cuesta topography to give an interdigitate coast of headlands and re-entrants. The major effect of glaciation was the deposition of a variety of glacial and glacio-fluvial sediments. Fluvial and ceastal erosion of these unconsolidated deposits. and of the unresistant bedrock supplies sediment to the littoral and nearshore environments. However, much of the river load is trapped in the drowned estuaries. The mafor source of littoral sediments at present. is the transportation of material toward the southwest into this unit. Kranck (1971) noted that there is a large deposit of well; sorted medium-grained sand that extends south and east of East Point in the adjacent shallow offshore zone.

Since deglaciation the rise of sea level has always been greater than isostatic readjustment. Radio-carbon dating by Frankel and Crowl (1961) indicates a submergence of 2 to $3 \mathrm{~m}$ during the last 900 years. This value agrees with an analysis of tide-gauge records from Charlottetown that show a submergence on the order of $2.5 \mathrm{~m} / 1000$ years (Farquharson 1959), and with an analysis of cores from Basin Head (Palmer 1974).

The tidal range on this coast is $1.0 \mathrm{~m}$ at mean tides and $1.8 \mathrm{~m}$ at large tides (Table 3 ). The prevailing and dominant winds are offshore (Summerside: Fig. 5, Table 6), and this coast is sheltered from all waves except those out of the eastern quadrant. The characteristic feature of the wave climate is the infrequent effect of high-energy conditions during periods of northeast storm winds. Waves out of the northeast, and waves out of the northwest and north that are refracted around East point give rise to a prevailing littoral drift direction from northeast to southwest. In the northern section of this unit, immediately adjacent to East Point, large beach-ridge complexes have developed at South Lake, Basin Head Harbour, and Little Harbour. To the south of this zone of deposition, away from the source of sediment transported around East Point, bay-mouth or mid-bay bars have developed across some of the shallow re-entrants. These barriers are low in height and limited in size owing to the low rates of sediment supply to the nearshore and littoral zones from offshore or from coastal erosion. The large beach system at Basin Head is a deposit of 31 parallel beach ridges (Fig. 12) that developed between 2000 and 1000 years B.P. but is now undergoing slow erosion (Palmex, 1974).

\section{Antigonish - West Cape Breton Island}

The eastern shore of the southern Gulf is an upland resistant coast, with few sediments, that is interrupted by the St. Georges Bay embayment (see next unit). Geologically, this unit has two distinct sections. Northeast of Cheticamp (Point Enragée) resistant Precambrian granites form an upland area that rises abruptly from the coast. To the southwest red-brown Mississippian sandstones (Fig. 3) form a low resistant cliffed coast. The general southwest-northeast trend of the coast is associated with the regional structure of the Appalachian system. The offshore gradients along this coast are steep (Inverness: Fig. 4). In general, surficial sediments are thin and discontinuous, though tills and fluvial outwash mantle the Mississippian sandstones in the southwest.

Littoral sediments are scarce in this unit owing to the relatively steep offshore gradients and to the resistant nature of the coastal bedrock. Rates of coastal erosion are low. At Inverness a rate of only 0.05 to $0.10 \mathrm{~m} /$ year is reported, even though the sandstone outcrops are exposed to long fetches to the northwest across the Gulf (Bowen et al 1975).

Although wave energy levels are highest on this eastern section of the southern Gulf coast (Northern Cape Breton Island: Table 5), the southern half of this unit is sheltered from waves out of the northwest by Prince Edward Island. On the more exposed northern sections energy levels are greatest, but this high energy is offset by the very resistant nature of the exposed granitic rocks. The presence of ice on the coast and on the adjacent coastal 

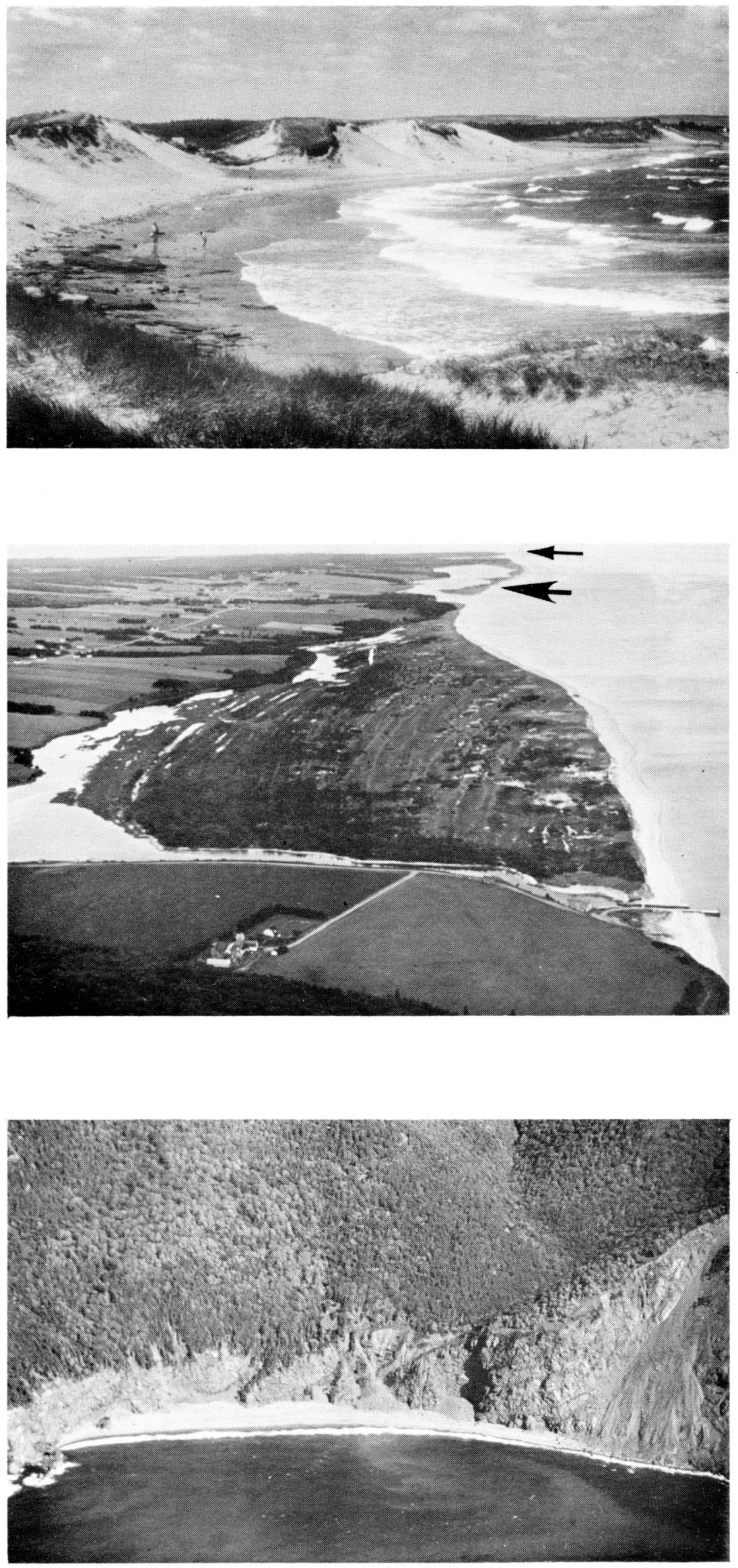

FIG. 11 Cavendish Beach, P.E.I. The barriers have developed in a relatively high wave-energy environment. The beach undergoes a summer-winter cycle and in this photo (taken in August) rock outcrops, normally only exposed in winter months, are present in the intertidal zone.

FIG. 12 Basin Head, eastern P.E.I. This aerial view to the northeast includes the beach-ridge complex of Basin Head and the barrier system that encloses South Lake (marked by the arrow). Beyond South Lake the coast turns abruptly to the west (left) at East Point (small arrow).

FIG. 13 Small pocket beach of pebblecobble sediments on the upland cliffed coast of west Cape Breton Island north of Cheticamp. 
waters for 4 to 5 months is very significant as this ice cover occurs at the time of strong onshore winds (Sumerside, sydney: Fig. 5). As this coast is affected primarily by waves out of the northwest quadrant, longshore transport in the littoral zone is dominantly to the southwest.

This coastal unit is one of resistant cliffs, and there are few areas of sediment accumulation. Beaches occur primarily as pockets of coarse sediments in sheltered embayments (Fig. 13) where littoral processes have been able to erode along secondary faults or joints in the resistant rocks. Spits have developed across inlets at Margaree and Inverness, and offshore bars of poorly sorted gravelly sand (Loring and Nota 1973) are particularly well developed off Inverness. Elsewhere, beaches are narrow and generally of coarse (pebble-cobble). sediments (Owens 1974b). A 1781 survey of Port Hood Island, $b$ Des Barres, shows that the island was connected to the mainland by a wide barrier beach. Between 1823 and 1830 a passage was cut through the barrier for fishing boats, and subsequent erosion formed a $1 \mathrm{~km}$-wide gap up to $3 \mathrm{~m}$ deep (McIntosh 1919). In the period 1958-1959 a submerged boulder breakwater was built out to the island with the expectation that sand would rapidy accumulate to form a new barrier beach. As yet very little sand has accumulated, a fact that illustrates the very low rate of sedimentation that is typical of this coast.

\section{St. Georges Bay}

St. Georges Bay is a sheltered environment set back from the main trend of the coast. The Carboniferous bedrock is predominantly sandstone but includes some conglomerates and shales, and is a low-lying area that is ma tled $y$ thick s rficial till deposits. Coastal gradients are low and, although this is a sheltered environment, in terms of wave-energy levels, cliff erosion has provided sufficient sediment for extensive spit and barrier development at the head of the bay.

Wave-energy levels are highest on the west coast, which is more exposed to waves from the north. and as a result transport of sand on this shore is to the south. A large system of prograding beach. ridges at Pomquet is estimated to have prograded seaward at a rate on the order of $1 \mathrm{~m} /$ year over the past 1000 years (Bowen et al 1975). This accumulation rȩquires a sediment input on the order of $50,000 \mathrm{~m} /$ year, a value similar to the estimated transport rates along the northeastern coast of New Brunswick. Sand transport on the eastern shore is also to the south, and a long, low sand-pebble barrier has developed in the most southerly section of this coast. It is unlikely that any of the sediment from the eastern shore is fed to the beaches at the head of the bay because of the deep water $(>40 \mathrm{~m})$ on the northem side of the causeway that now blocks the strait of Canso.

\section{ATLANTIC NOVA SCOTIA}

The Atlantic coast of Nova Scotia is a resistant rocky coast that follows the regional southwesterlynortheasterly Appalachian trend. The only upland section is in the northeast where the Cape Breton
Highlands are directly adjacent to the coast. The remainder of this unit is a predominantly lowlying coast of metamorphic and igenous rocks that has been drowned, and an intricate shoreline of bays and islands has resulted. Erosion of less resistant sedimentary rocks that outcrop in northern Chedabucto Bay, eastern Cape Breton Island and parts of southeastern Cape Breton Island (Fig. 3) provides sediment directly to the littoral zone. In these areas beaches have developed across embayments and estuaries. Elsewhere, littoral sediments are very scarce, and the coast is characterized by resistant white rock outcrops and high wave-energy conditions. This situation is particularly true in the Eastern Shore unit (Fig. 14, Table 7), which is the longest $(3,000 \mathrm{~km})$ and one of the most homogeneous subdivisions in the Maritime Provinces.

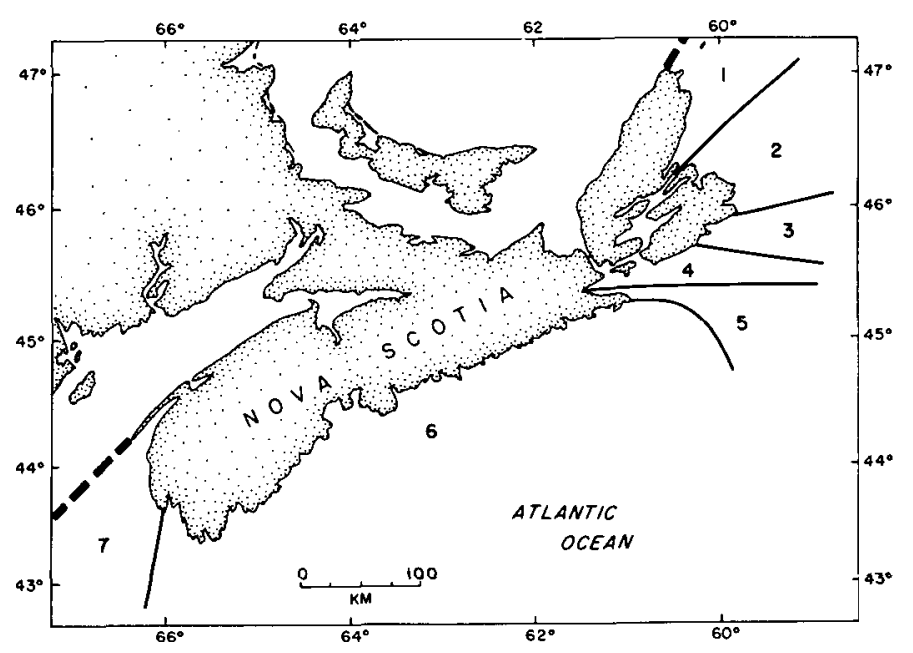

FIG. 14 Subdivisions of Atlantic Nova Scotia (see Table 7). 1. Northeast Cape Breton Island, 2. East Cape Breton Island, 3. Southeast Cape Breton Island, 4. North Chedabucto Bay, 5. South Chedabucto Bay, 6. Eastern Shore, 7. Western Shore.

Northeast Cape Breton Island

This upland coast is characterized by resistant cliffs primarily of Devonian metamorphic and igneous rocks. Precambrian granites outcrop at Cape Egmont and form a spectacular ridge on the north side of the Aspey Fault which extends northeast to Cape North. A few areas of Mississippian sandstones occur in low-lying areas in Aspey Bay and St. Anne's Bay. Offshore gradients are steep, and few sediments have accumulated in the littoral zone except in sheltered embayments. The sediments are derived primarily from local thick till deposits.

The coast is directly exposed to the North Atlantic and is a high wave-energy environment (Northern Cape Breton Island: Table 5). Two factors act to reduce energy levels: winds and ice. The prevailing and dominant winds on this coast are offshore (Sydney: Fig. 5); so the coast is largely protected from waves generated 
Characteristics of the Coastal Environments of Atlantic Nova Scotia

\begin{tabular}{|c|c|c|c|c|c|c|c|}
\hline \multicolumn{2}{|c|}{ Subdivision } & \multirow{2}{*}{$\begin{array}{l}\text { Geological } \\
\text { Character } \\
\text { Resistant } \\
\text { metamorphic } \\
\text { and igneous } \\
\text { rocks; thin } \\
\text { till cover }\end{array}$} & \multirow{2}{*}{$\begin{array}{l}\begin{array}{l}\text { Backshore } \\
\text { Relief }\end{array} \\
\begin{array}{l}\text { Upland cliffed } \\
\text { coast }(5-100 \mathrm{~m})\end{array}\end{array}$} & \multirow{2}{*}{\begin{tabular}{l}
\multicolumn{1}{c}{$\begin{array}{c}\text { Beach } \\
\text { Character }\end{array}$} \\
Absent or \\
narrow: coarse \\
sediments
\end{tabular}} & \multirow{2}{*}{$\begin{array}{l}\begin{array}{c}\text { Fetch and } \\
\text { Wave Exposure }\end{array} \\
\text { Exposed open } \\
\text { ocean ocast: } \\
\text { ice-free 8-9 months }\end{array}$} & \multirow{2}{*}{$\begin{array}{c}\begin{array}{c}\text { Mean Tidal } \\
\text { Range }\end{array} \\
1 \mathrm{~m}\end{array}$} & \multirow{2}{*}{$\begin{array}{c}\begin{array}{c}\text { Sediment } \\
\text { Availability }\end{array} \\
\text { Very scarce }\end{array}$} \\
\hline 1. & $\begin{array}{l}\text { Northeastern } \\
\text { Cape Breton } \\
\text { Island }\end{array}$ & & & & & & \\
\hline 2. & $\begin{array}{l}\text { Eastern Cape } \\
\text { Breton Island }\end{array}$ & $\begin{array}{l}\text { Carboniferous } \\
\text { sandstone or } \\
\text { shale; thin till } \\
\text { cover }\end{array}$ & $\begin{array}{l}\text { Rocky cliffs } \\
(5-20 \mathrm{~m})\end{array}$ & $\begin{array}{l}\text { Occasional } \\
\text { spits and } \\
\text { barriers }\end{array}$ & $\begin{array}{l}\text { Exposed >500 km } \\
\text { ice-free } 8-9 \\
\text { months }\end{array}$ & $1 \mathrm{~m}$ & Scarce \\
\hline 3. & Southeastern & $\begin{array}{l}\text { Carboniferous } \\
\text { sedimentary and } \\
\text { and metasediment- } \\
\text { ary rocks; thick } \\
\text { till and drumlins }\end{array}$ & $\begin{array}{l}\text { Low rock and } \\
\text { till cliffs } \\
(10-20 \mathrm{~m})\end{array}$ & $\begin{array}{l}\text { Barrier } \\
\text { beaches }\end{array}$ & $\begin{array}{l}\text { Exposed open } \\
\text { ocean coast ice } \\
\text { in sheltered areas } \\
\text { up to } 3 \text { months }\end{array}$ & $1 \mathrm{~m}$ & $\begin{array}{l}\text { Scarce, but } \\
\text { locally abundant }\end{array}$ \\
\hline & $\begin{array}{l}\text { Northern } \\
\text { Chedabucto Bay }\end{array}$ & $\begin{array}{l}\text { Carboniferous } \\
\text { sedimentary } \\
\text { rocks, some } \\
\text { resistant vol- } \\
\text { canics, abundant } \\
\text { till }\end{array}$ & $\begin{array}{l}\text { Low rock and } \\
\text { till cliffs up } \\
20 \mathrm{~m}\end{array}$ & $\begin{array}{l}\text { Spits and } \\
\text { barrier; coarse } \\
\text { sediments }\end{array}$ & $\begin{array}{l}\text { Exposed in north- } \\
\text { east, elsewhere } \\
\text { sheltered }(<50 \mathrm{~km}) \\
\text { ice-free } 8-9 \text { months }\end{array}$ & $1.5 \mathrm{~m}$ & Abundant \\
\hline 5. & $\begin{array}{l}\text { Southern } \\
\text { Chedabucto } \\
\text { Bay }\end{array}$ & $\begin{array}{l}\text { Resistant meta- } \\
\text { sedimentary and } \\
\text { igneous rocks; } \\
\text { fault-line coast; } \\
\text { very thin till }\end{array}$ & $\begin{array}{l}\text { Rocky. cliffs } \\
(3-10 \mathrm{~m})\end{array}$ & $\begin{array}{l}\text { Absent or narrow; } \\
\text { coarse sediments }\end{array}$ & $\begin{array}{l}\text { Sheltered }(50 \mathrm{~km}) \\
\text { ice-free } 8-9 \text { months }\end{array}$ & $1.5 \mathrm{~m}$ & Very scarce \\
\hline 6. & Eastern Shore & $\begin{array}{l}\text { Resistant meta- } \\
\text { sedimentary and } \\
\text { granitic rocks; } \\
\text { variable thick- } \\
\text { ness tills and } \\
\text { drumlins }\end{array}$ & $\begin{array}{l}\text { Indented low } \\
\text { rocky coast, some } \\
\text { eroded drumlins } \\
(30 \mathrm{~m})\end{array}$ & $\begin{array}{l}\text { Absent or } \\
\text { barriers or pocket } \\
\text { beaches in } \\
\text { re-entrants; } \\
\text { coarse }\end{array}$ & $\begin{array}{l}\text { Exposed open ocean } \\
\text { coast, embayments } \\
\text { sheltered: ice in } \\
\text { sheltered areas } \\
2-3 \text { months }\end{array}$ & $1-2 \mathrm{~m}$ & Very scarce \\
\hline & Western Shore & $\begin{array}{l}\text { Resistant sedi- } \\
\text { mentary and meta- } \\
\text { morphic rocks; } \\
\text { thin till deposits }\end{array}$ & $\begin{array}{l}\text { Till or rock } \\
\text { cliffs }(3-30 \mathrm{~m})\end{array}$ & $\begin{array}{l}\text { Narrow or } \\
\text { coarse-sediment } \\
\text { barriers }\end{array}$ & $\begin{array}{l}\text { Variable locally } \\
\text { very exposed: } \\
\text { local ice up to } \\
2 \text { months }\end{array}$ & $4 \mathrm{~m}$ & $\begin{array}{l}\text { Scarce, but } \\
\text { locally }\end{array}$ \\
\hline
\end{tabular}

(see Fig. 7) 
locally from winds out of the western quadrant. Ice is present on the coast for up to 4 months each year and further acts to reduce wave activity on the shoreline.

This bold upland coast follows the southwestnortheast structural trends of the Appalachian System and rises to elevations of $200 \mathrm{~m}$ within a few kilometers of the shoreline. Despite the high relief, much of the littoral zone is characterized by a low rocky shore, and cliffs are generally less than $20 \mathrm{~m}$ in height. There are few beach deposits, and the four significant localized accumulations occur in St. Lawrence Bay, Aspey Bay, South BayIngonish, and St. Anne's Bay. In Aspey Bay the long, low sand barrier is frequently over-washed through a series of regularly spaced channels that separate high areas of dune grass. The barrier in South BayIngonish consists primarily of cobble sediments, but locally derived red-brown sands occur in the lower intertidal zone.

\section{East Cape Breton Island}

The shoreline of this unit is irregular as the regional structural trends of the Carboniferous and Pennsylvanian sandstones and shales are approximately perpendicular to the coast. The outcrops are relatively unresistant, and erosion rates up to $0.5 \mathrm{~m} /$ year have been reported (Johnson 1925). Cliff erosion is the primary source of littoral zone sediments, but glacial till deposits are generally thin and discontinuous.

The coast is exposed to the northeast but is largely sheltered from waves out of the south and east. Ice on the shoreline acts to limit the effects of waves for up to 4 months each year and sea ice concentrations can be heavy along the coast and in embayments.

The coastal geomorphology of this section is primarily one of low, irregular cliffs. Several sand barrier beaches have developed, at Florence, Dominion and Glace Bay, from the accumulation of the products of local erosion. One feature of these beaches is the small, but very noticeable, coal content. The fine coal particles tend to stay in suspension in the breaking waves close to shore. All the major beaches have been greatly affected by human activity, particularly sand and gravel removal.

\section{Southeast Cape Breton Island}

Southeast Cape Breton Island is a low-relief coast of predominantly resistant Precambrian rocks that parallels the regional structural trends. The bedrock is overlain by thin till deposits and some. drumlin accumulations, particularly in the Framboise area. Erosion rates are high locally, and Bowen et al (1975) report such a rate of $0.25 \mathrm{~m} /$ year for exposed drumlins. Using evidence from the Fortress: Louisbourg, Grant (1970) indicates that sea level on this coast has risen approximately $1 \mathrm{~m}$ in the last 250 years.

The coast is exposed to wave activity and, although no data are available for the coastal waters, Neu (1971) indicates that on the adjacent shelf there is a marked seasonal difference in wave energy levels and that maxima occur in the period November to March. Neu (1972). also notes that the coast is protected from strong northwesterly winds in winter, a circumstance that reduces wave-energy levels in these months by opposing waves generated in the Atlantic. The predominance of winds out of the south in sumer months (Sydney: Fig. 5) generates a longshore sediment transport that is toward the northeast along most exposed sections of the coast. Waveenergy levels on the exposed coast are little affected by ice, but ice is present in enclosed bays for up to 4 months each year.

The low-relief, resistant rocky character of most of this coast is interrupted by several welldeveloped barrier or tombolo systems. These accumulations are generally poorly sorted sand and gravel deposits and are particularly well developed at Point Michaud and in Framboise and Forchu Bays. The sediments have accumulated as a result of present-day erosion and by the shoreward movement of sediments with the rising sea level. Many of the beaches have been subject to sediment removal following closure of the beaches on the east coast of Cape Breton Island.

Northern Chedabucto Bay

The north shore of Chedabucto Bay is a drowned Carboniferous lowland region. The unresistant conglomerates, sandstones, and shales were folded about north-trending axes and subsequently eroded by fluvial and glacial processes to form an undulating plateau (Grant 1971a, 1974). The most important effect of glaciation was the deposition of extensive locally derived red-loam tills. The major physiographic feature of the north shore is the Strait of Canso, a deep (up to $60 \mathrm{~m}$ ), narrow channel that connects Chedabucto Bay with St. Georges Bay in the southern Gulf of St. Lawrence. This glacially eroded U-shaped channel was blocked in 1955 by construction of a causeway to link cape Breton Island with mainland Nova Scotia. Elsewhere on the north shore, backshore and offshore gradients are low and the postglacial rise in sea level has produced a complex series of islands and inlets in low-lying areas, or an embayment-headland shoreline in areas of slightly higher relief. Relative sea level continues to rise at the present at a rate of about $1.5 \mathrm{~m} / 1000$ years (Grant 1970).

On coasts directly open to wave action, till cliffs erode rapidly, 0.5 to $1.5 \mathrm{~m} /$ year (Owens and Rashid 1976), and embayments have been closed by deposition and the development of spits or bay-head barriers. Sediments are derived from contemporary erosion of the till outcrops and also from the products of earlier erosion and the landward migration of barriers during the post-glacial rise of sea level (Owens 1971). Little material is supplied by present-day fluvial processes. The beaches are composed largely of coarse-grained sediments (pebble-cobble), and rates of sediment supply are low as a result of the limited extent of coastal till outcrops; thus, sediment removal by man from beaches has resulted in shoreline retreat (Owens and Drapeau 1973, Owens and Rashid 1976). In sheltered areas, particularly east of the strait of Canso, the beaches are narrow and 
are composed of a thin ( 30 to $40 \mathrm{~cm}$ ) layer of poorly sorted sediments that rest on eroded till platforms.

Tides are semi-diurnal and range between 1.3 and $2.0 \mathrm{~m}$. Littoral processes are dominated by the effects of locally generated storm waves; maximum wave heights occur in winter months (Decembex to May). Long-period waves $(>8$ s) out of the Atlantic are refracted offshore due to the low gradients on the north part of the Bay, so that relatively little energy reaches the beach from these swell waves. Prevailing winds are out of the southwest or northwest, but in winter months maximum wind velocities are out of the southeast and northeast and are associated with cyclonic depressions (Owens 1971, Table 2). Ice is an important factor in limiting beach processes during winter months, and is especially important in sheltered environments. The sea ice cover is rarely 1008, and the Bay is frequently ice-free, particularly following periods of winds out of the westerly quadrant.

Owens (1971) states that this 525-km section of coast can be subdivided as follows: sand beaches, 3\%; gravel-shingle beaches, 35\%; boulder beaches, 4\%; rock, 10\%; till, 17\%; and low-energy environments, 31\%. The majority of the beaches occur west of the Strait of Canso, where the submergence of the Carboniferous lowlands led to development of a series of embayments and headlands. Erosion of the unresistant sandstone, conglomerate or till headlands and deposition across the embayments have produced a relatively straight coast on which the primary direction of longshore sediment transport is from northeast to southwest (Owens and Rashid 1976). East of the Strait of Canso the undulating Carboniferous lowland has been drowned and is now characterized by a complex series of islands and bays in an area of low relief. The outer coasts have a series of eroding headlands and barrier or bayhead beaches, but in sheltered low-energy areas reworking and redistribution of littoral sediments is minimal. These low-energy coasts usually consist of slowly eroding low-relief till cliffs or a low berm, and beaches of a thin (30 to $40 \mathrm{~cm}$ ) layer of poorly sorted fine- and coarse-grained sediments that overlie a wave-cut till platform. Although there are many sheltered areas suitable for the accumulation of fine-grained sediments, few areas of marsh have developed in this region.

The south and east coasts of Isle Madame are more rocky than elsewhere due to local outcrops of resistant Precambrian and Devonian rocks. Sand beaches are rare throughout this unit as a result of the composition of the sediment sources (loam or gravel tills). Large tombolos are common on the exposed coast, and the best examples are at Ragged Head and St. Peter's Island (Owens 1971, Fig. 25).

\section{South Chedabucto Bay}

Formation of this structurally controlled faultline coast resulted from differential erosion along the boundary between a partially submerged fault block of unresistant Carboniferous sediments to the north and an uplifted resistant block of lower Paleozoic intrusive and metamorphic rocks to the south (Fig. 3). This straight coast is characterized by low, resistant cliffs and intertidal rock platforms. Offshore gradients are steep $(1: 20)$ and adjacent to the coast the upland plateau rises to $120 \mathrm{~m}$ in the west and 30 to $50 \mathrm{~m}$ in the east. Pocket beaches occur where embayments have been formed by erosion along secondary faults or joint planes. Glacial deposition was limited in this area by the resistant nature of the local bedrock and, where tills are present, they are both stoney and thin. Sediments are scarce in the littoral zone as marine erosion produces little new material, except adjacent to the few coastal till outcrops. The rocky coast is largely devoid of sediments, and the only significant accumulations occur in the sheltered pocket beaches. At these locations the sediments are in the pebble-cobble range.

The characteristic features of this coast are related primarily to physiographic and geologic factors, rather than to the processes acting upon the resistant outcrops. Shoreline changes occur at a very slow rate, and little sediment is available in the littoral zone for transport and redistribution. Because of the steep nearshore and backshore slopes, the relative rise of sea level (15 cm/century, Grant 1970) has produced few shoreline changes during the last millennium. Owens (1971) subdivides this 90-km section of coast as follows: sand beaches, $0 \%$; gravel-shingle beaches, 19\%; boulder beaches, 28; rock, 58\%; till, 118; and low-energy environments, 9\%.

\section{Eastern Shore}

This entire section of lowland coast is a single major unit of resistant rocks covered by varying thicknesses of glacial drift. The southwestnortheast orientation of the coast follows the regional structural trends of the Appalachian system. The resistant Cambrian-Devonian granitic and mata-sedimentary rocks were exoded by the Pleistocene ice sheets, and the post-glacial rise of sea level has drowned this lowland coastal area to produce a complex shoreline consisting of inlets, islands, reefs, and embayments.

The general scarcity of sediments is evident in most areas but, where material is available for reworking, embayments have been closed by barriers, spits and tombolos. Little sediment is supplied to the coastal zone by rivers, and only a limited amount is supplied by local erosion of glacial deposits, although erosion of these deposits is rapid, e.g., $2 \mathrm{~m} /$ year at Hartlen Point, to the east of Halifax Harbour. These erosion sources are significant locally, but the major source of material has been from the shoreward migration of littoral zone sediments during the rise of sea level. This trend is evidenced by the identification of the ratio between resistant quartz and the more friable augite and rock fragments in offshore sediments, which represent a lag deposit as material has been winnowed and redistributed landward.

The mean tidal range increases from $1 \mathrm{~m}$ in eastern 
TABLE 8

Scotian Shelf Wave Data - 1970 (m)

Significant Wave Height Once/Year

E. Gulf of Maine
SW Nova Scotia
Halifax

5.5

6.0

SE Nova Scotia

6.6

7.2

(from Neu, 1972)

sections to $2 \mathrm{~m}$ near Cape Sable and to $3.7 \mathrm{~m}$ at Yarmouth. The coast is an exposed wave-energy environment that experiences a marked increase in energy levels in winter months (Neu 1972) and is occasionally subject to extra-tropical storms that cross the area from the southwest in late summer or fall. Neu (1972) notes that wave-energy levels increase toward the northeast on the adjacent shelf (Table 8) and significant wave heights greater than $4 \mathrm{~m}$ are common in winter months despite the predominance of offshore winds (Halifax: Fig. 5). Ice is not an important factor on the exposed outer coast but is present in sheltered inlets and bays for periods of 3 to 4 monthis each winter.

The low rocky coasts that characterize the exposed outer shoreline (Fig. 15) is in contrast to the very sheltered, low wave-energy environments in the many bays and inlets. Where sediment is available locally or where material has been moved landward with the rising sea level, beaches of sand (Martinique Beach) or pebble-cobble (Fancy's Point, Guysborough County) have developed. In addition to these large beach systems, there are many smaller pocket beaches (Fig. 16) or tombolos (Schwartz 1967). In all cases these beaches are slowly migrating landward, and there are no known areas where beach progradation is occurring. Due to the marked seasonal difference in wave energy levels, the beaches have a cycle of summer accretion and winter

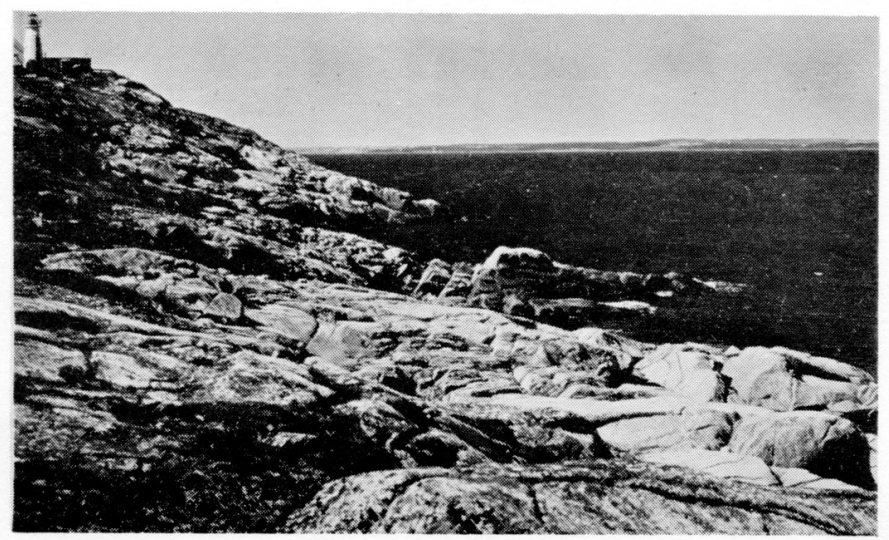

FIG. 15 Resistant lowland rocky coast typical of Atlantic Nova Scotia. Chedabucto Head near Halifax. erosion. Despite the low tidal range in most areas, salt marshes are common and are of ten extensive (Fig. 17) because of the complex nature of the shoreline.

\section{Western Shore}

The western shore is similar geologically to the eastern shore but is relatively protected from Atlantic waves. To the north the resistant CambrianDevonian rocks give way to a band of unresistant Triassic rocks that have been eroded to form St. Mary's Bay. The north shore of this bay is a resistant Triassic basalt dyke that trends southwesterly. The peninsula that forms the western section of the dyke is interrupted by two northsouth faults that offset Brier Island and Long Island to the north (Fig. 3). Ice moved across the area toward the southeast, and the eroded lowland was overlain by till and fluvial outwash deposits. Where these deposits occur along the coast they are being actively eroded by waves and are a primary source of sediments for the ilittoral zone.

Mean tidal range increases toward the north and northeast from $3.7 \mathrm{~m}$ at Yarmouth to $4.7 \mathrm{~m}$ in $\mathrm{St}$. Mary's Bay. Strong tidal currents (up to $3 \mathrm{~m} / \mathrm{s}$ ) occur in the constricted passages between Long and Brier Islands and between Digby Neck and Brier Island (Canadian Hydrographic Service 1976). Although the coast is relatively sheltered from the Atlantic (Table 8), it is subject to oblique wave attack as waves are refracted into the eastern Gulf of Maine. These waves generate strong longshore currents that transport sediment toward the north and northeast in the littoral zone. Wave action is rarely limited by ice on the exposed coasts, but ice forms and persists for up to 2 months each winter in sheltered areas.

Locally derived littoral sediments are more plentiful toward the northeast and are usually a mixture of sand and pebble-cobbles, but wide lowtide flats have developed in south and east St. Mary's Bay. The steep north shore of St. Mary's Bay is largely devoid of littoral sediments.

The coast of this unit is relatively straight.

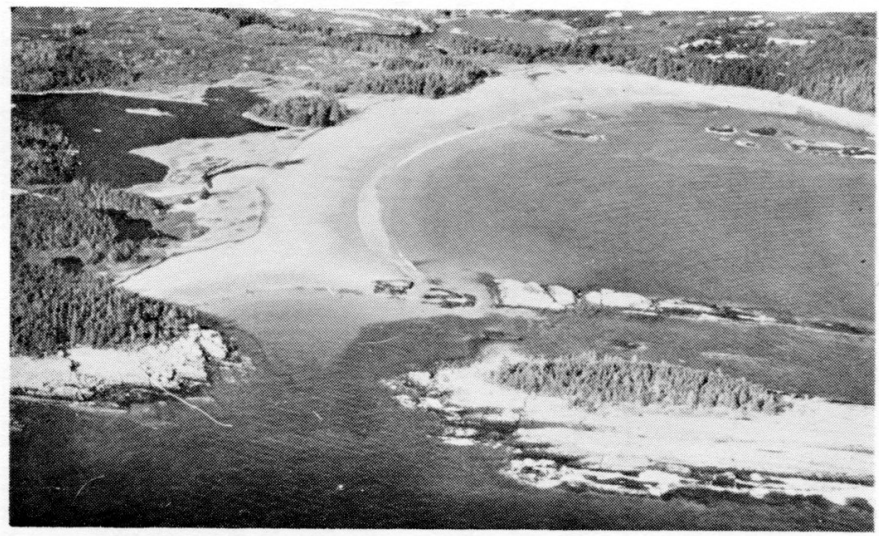

FIG. 16 Pocket beach of pebble-cobble sediments near Musquodoboit, N.S. 
TABLE 9

Characteristics of the Coastal Environments of the Bay of Fundy

\begin{tabular}{|c|c|c|c|c|c|c|}
\hline Subdivision & $\begin{array}{l}\text { Geological } \\
\text { Character }\end{array}$ & $\begin{array}{l}\text { Backshore } \\
\text { Relief }\end{array}$ & $\begin{array}{c}\text { Beach } \\
\text { Character }\end{array}$ & $\begin{array}{l}\text { Fetch and } \\
\text { Wave Exposure }\end{array}$ & $\begin{array}{l}\text { Mean Tidal } \\
\text { Range }\end{array}$ & $\begin{array}{l}\text { Sediment } \\
\text { Availability }\end{array}$ \\
\hline 1. South Shore & $\begin{array}{l}\text { Resistant Triassic } \\
\text { basalt dyke; } \\
\text { parallels coast }\end{array}$ & $\begin{array}{l}\text { Low rocky } \\
\text { coast or cliffs } \\
\text { up to } 30 \mathrm{~m}\end{array}$ & $\begin{array}{l}\text { Absent or narrow } \\
\text { cobble beach at } \\
\text { high water mark, } \\
\text { with wide inter- } \\
\text { tidal platform }\end{array}$ & $\begin{array}{l}\text { Sheltered } \\
(50 \mathrm{~km})\end{array}$ & $6-10 \mathrm{~m}$ & Very scarce \\
\hline $\begin{array}{l}\text { 2. Head of the } \\
\text { Bay }\end{array}$ & $\begin{array}{l}\text { Resistant conglomerates, } \\
\text { basalts or granites }\end{array}$ & $\begin{array}{l}\text { Cliffed coast, } \\
\text { up to } 200 \mathrm{~m}\end{array}$ & $\begin{array}{l}\text { Absent or large } \\
\text { pocket beaches } \\
\text { pebble-cobble on } \\
\text { beachface and mud } \\
\text { overlying coarse } \\
\text { seds in inter- } \\
\text { tidal zone }\end{array}$ & $\begin{array}{l}\text { Exposed } \\
(50-100 \mathrm{~km})\end{array}$ & $10 \mathrm{~m}$ & $\begin{array}{l}\text { Scarce, but } \\
\text { locally abundant }\end{array}$ \\
\hline 3. Minas Basin & $\begin{array}{l}\text { Triassic sandstone } \\
\text { and shales, or un- } \\
\text { consolidated glacial } \\
\text { deposits }\end{array}$ & $\begin{array}{l}\text { Cliffs, up } \\
\text { to } 30 \mathrm{~m}\end{array}$ & $\begin{array}{l}\text { Wide intertidal } \\
\text { mud or sand flats } \\
\text { on rock platform, } \\
\text { pebble-cobble beach } \\
\text { at high water mark, } \\
\text { marshes in sheltered } \\
\text { areas }\end{array}$ & $\begin{array}{l}\text { Very sheltered } \\
(<50 \mathrm{~km})\end{array}$ & $>10 \mathrm{~m}$ & Abundant \\
\hline 4. Chignecto Bay & $\begin{array}{l}\text { Permo-Carboniferous } \\
\text { sandstone and shale }\end{array}$ & $\begin{array}{l}\text { Cliffs, up } \\
20 \mathrm{~m}\end{array}$ & $\begin{array}{l}\text { wide intertidal } \\
\text { mud flats on rock } \\
\text { platform, pebble/ } \\
\text { cobble beach at high } \\
\text { water mark, extensive } \\
\text { marshes in sheltered } \\
\text { areas }\end{array}$ & $\begin{array}{l}\text { Very sheltered } \\
(<50 \mathrm{~km}) \\
\text { e }\end{array}$ & $>10 \mathrm{~m}$ & $\begin{array}{l}\text { Abundant } \\
\text {. }\end{array}$ \\
\hline 5. North Shore & $\begin{array}{l}\text { Resistant crystalline } \\
\text { rocks or Carboniferous } \\
\text { sediments and intru- } \\
\text { sives, thin till cover }\end{array}$ & $\begin{array}{l}\text { Cliffs } \\
\text { (west } 5-60 \mathrm{~m} \text { : } \\
\text { east }>100 \mathrm{~m} \text { ) }\end{array}$ & $\begin{array}{l}\text { Absent or coarse- } \\
\text { grained pocket } \\
\text { beaches }\end{array}$ & $\begin{array}{l}\text { Shel tered } \\
(<50 \mathrm{~km})\end{array}$ & $6-10 \mathrm{~m}$ & Very scarce \\
\hline 6. Northwest Shore & $\begin{array}{l}\text { Resistant metasedi- } \\
\text { mentary and sedimentary } \\
\text { rocks; thin till cover }\end{array}$ & $\begin{array}{l}\text { Low rocky } \\
\text { coast or } \\
\text { cliffs } 5-30 \mathrm{~m}\end{array}$ & $\begin{array}{l}\text { Absent or coarse- } \\
\text { grained and narrow }\end{array}$ & $\begin{array}{l}\text { Outer coast } \\
\text { exposed, rest } \\
\text { sheltered } \\
(<50 \mathrm{~km})\end{array}$ & $6 \mathrm{~m}$ & Scarce \\
\hline
\end{tabular}

(see Fig. 8) (after Owens 1977b) 
as the north coast is a linear dyke, and elsewhere barriers have developed across embayments between headlands. Where rock outcrops on the coast, relief is generally low, so that there are few cliffs, the exceptions being the north shore of St. Mary's Bay and the section between Cape St. Mary and Meteghan. The resistant north coast of St. Mary's Bay has cliffs up to $20 \mathrm{~m}$ high and is rocky; there are a few sections of beach sediments. East of Meteghan, bedrock is at, or below sea level and the coast is an alternating series of low eroding headlands of glacial sediments and cobble barriers. The character of the beaches is generally comprised of sand in the nearshore zone, pebblecobble intertidal sediments, a cobble berm, and occasionally sand dunes in the backshore. In southern St. Mary's Bay the longshore transport of sediments is frequently interrupted by wharves, jetties, or breakwaters that have been constructed at the many settlements along this coast. These obstructions particularly affect the pebble-cobble sediments on the upper beach, whereas the sand tends to be transported around the obstruction and into the harbours, where it is removed by dredging. Large depositional pebble-cobble cuspate forelands have developed where there are natural convergences of longshore sediment transport, such as at Majors Point and at Gilbert's Point.

\section{THE BAY OF FUNDY}

The Bay of Fundy, a large re-entrant in the northeastern Gulf of Maine, is characterized by tidal ranges that increase eastward from $5 \mathrm{~m}$ at the entrance to $15 \mathrm{~m}$ in the Minas Basin and Chignecto Bay (Table 3). Maximum tidal ranges of $21 \mathrm{~m}$ have been reported under storm conditions (Ganong 1903). The funnel shape of the Bay is a result of fluvial and glacial erosion along the regional Appalachian southwestnortheast structural trends. This configuration is particularly evident along the south shore from Brier Island to Scots Bay, where unresistant Triassic rocks have been eroded to expose a resistant dyke that was intruded along a structural weakness. Bifurcation at the head of the Bay occurs where the resistant upland area of the Cobequid Hills separates

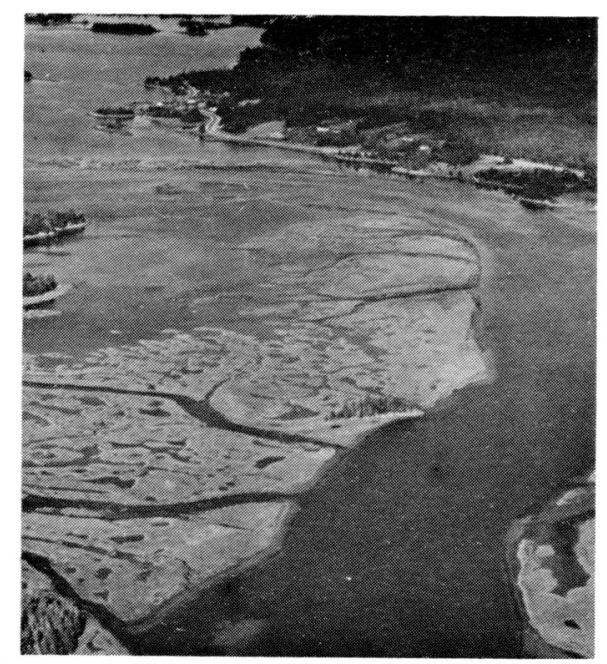

FIG. 17 Sheltered estuarine marsh near Musquodoboit, N.S.

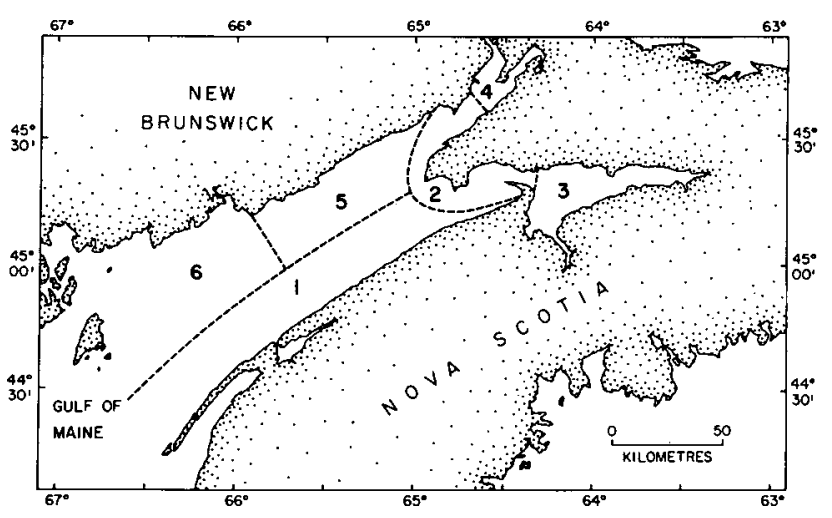

FIG. 18 Subdivisions of the Bay of Fundy (after Owens, 1977b) (see Table 9).

1. South Shore, 2. Head of the Bay, 3. Minas Basin, 4. Chignecto Bay, 5. North Shore, 6. Northwest Shore.

Chignecto Bay from the Minas Basin. Whereas Chignecto Bay follows the southwest-northeast regional structural trend erosion, associated with the eastwest trending Cobequid fault zone (which continues east to become the Chedabucto Bay fault zone (Fig. 3) and the southwesterly northeasterly trending Triassic beds, has produced the triangular shape of the Minas Basin. The Basin is separated from the main body of the Bay by the basalt dyke that curves to the north as it outcrops in the exposed limb of the Fundy syncline.

The coastline is subdivided into six units (Fig. 18, Table 9), based on variations in shoreline type that are controlled by the local geology and by tidal processes. A large proportion of the 1400 $\mathrm{km}$ of coast comprises rock outcrops, wide mud or sand intertidal flats and extensive marshes in the upper reaches of the Bay.

South Shore

The South Shore is a straight rocky coast that follows the exposure of a southwesterly-northeasterly trending resistant Triassic basalt dyke. The western section of the dyke is a thin peninsula that has been segmented by north-south faults. Brier Island and Long Island are slightly offset to the north (Fig. 3). The peninsula results from erosion of Triassic sedimentary rocks that outcrop immediately north and south of the dyke. The erosion of the unresistant outcrop that lies between the dyke and the Cambrian-Devonian metasedimentary rocks to the south has resulted in the formation of St. Mary's Bay and the Annapolis Basin. 


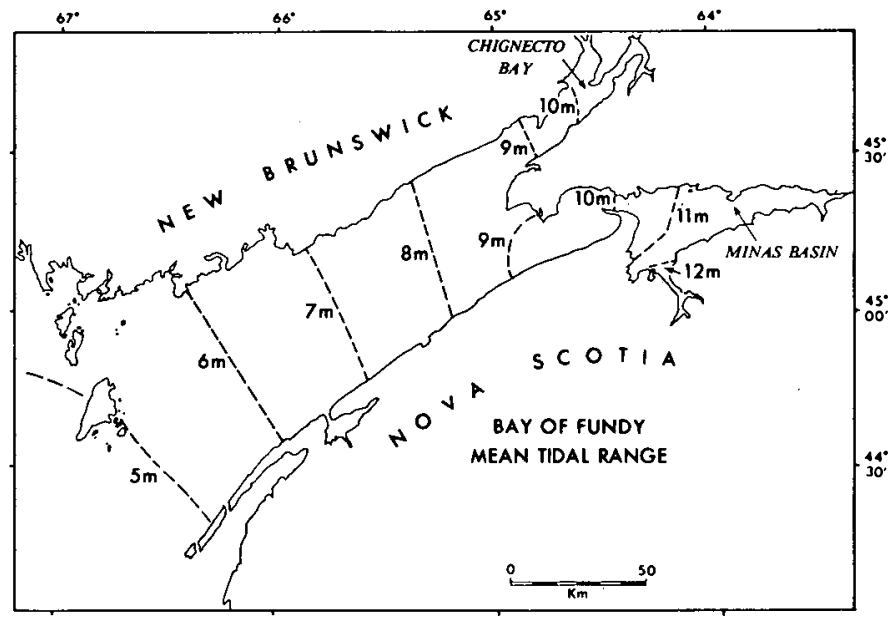

The region was glaciated by Laurentian ice that moved across the region to the southeast. As the ice retreated, the sea invaded the Bay of Fundy, and a calving bay (Prest and Grant 1969) was created. Recession to an upland ice-cap in southwestern Nova Scotia resulted. Quaternary deposits exposed along the coast are predominantly reddish-brown stoney tills. As the ice retreated, the land initially remained isostatically depressed and marine water submerged the coast. The limit of marine overlap is given as $45 \mathrm{~m}$ on Brier Island and $42 \mathrm{~m}$ on Digby Neck (Grant 1971b). In this region the isobases parallel the coast. Sea level fell rapidly owing to isostatic rebound; it crossed the site of the present shoreline about 10000 years B.P. and dropped to $30 \mathrm{~m}$ below present sea level between 8000 and 7000 years B.P. (Grant 1972). Thereafter, crustal rebound was exceeded by the eustatic sea level rise and the coast was resubmerged at a rate of $30 \mathrm{~cm} /$ century. This high rate has been attributed partly to tidal amplification as sea level rose, and partly to resultant water loading (Grant 1970).

Mean tidal range of the semi-diurnal tides increases from $4.7 \mathrm{~m}$ on Brier Island, at the entrance of the Bay, to $9.9 \mathrm{~m}$ at Baxters Harbour, at the eastern limit of this unit (Fig. 19). (where spring tidal ranges are $6.5 \mathrm{~m}$ and $13.7 \mathrm{~m}$, respectively). Strong tidal currents ( 2 to $3 \mathrm{~m} / \mathrm{s}$ ) occur between Long Island and Brier Island, between Digby Neck and Long Island, and in Digby Gut (Canadian Hydrographic Service 1976). The importance of waves. generated in the Atlantic decreases to the east but, as the dominant and prevailing winds are out of the westerly quadrant (Fig. 5, Table 6), this coast is exposed to locally-generated waves. throughout the year. Swift et al (1973) indicate that in the Bay wave heights are $>3.6 \mathrm{~m}$ in summer and $>4.0 \mathrm{~m}$ in winter for $10 \%$ of the time. The major limiting factor on the effectiveness of wave action in the littoral zone is the large vertical range over which the wave energy is dissipated. Sea ice is present from January to April, but the Bay is never frozen over and in some years little ice forms at all. Wave action, therefore, is not severely limited during winter months. Beach-fast ice or an ice foot develops but may not be present throughout the winter; rather, it may freeze and thaw periodically.

Littoral sediments are scarce throughout this section of coast. West of Digby little or no sediments occur in the shore zone, whereas to the east, pebble, cobble, or boulder material is frequently present at the high water mark and in the intertidal zone (Fig. 20). Sediment transport directions are primarily to the northeast as waves approach predominantly out of the western quadrant. This coast is straight and rocky, and no marshes or dunes are present on the open coast. However, in the sheltered Annapolis: Basin extensive marsh development has occurred in this area of wide intertidal sand and mud deposits. On the open coast the intertidal rock platforms are covered with seaweeds, primarily Fucoids: and Laminaria.

The shore west of Digby Gut is characterized by a low rocky coast. Occasional pocket beaches have acted as sediment traps and small well developed beaches of medium- and coarse-grained material have
FIG. 19 Mean tidal range in the Bay of Fundy (source: Canadian Hydrographic Service, 1975b) (see also Table 3).

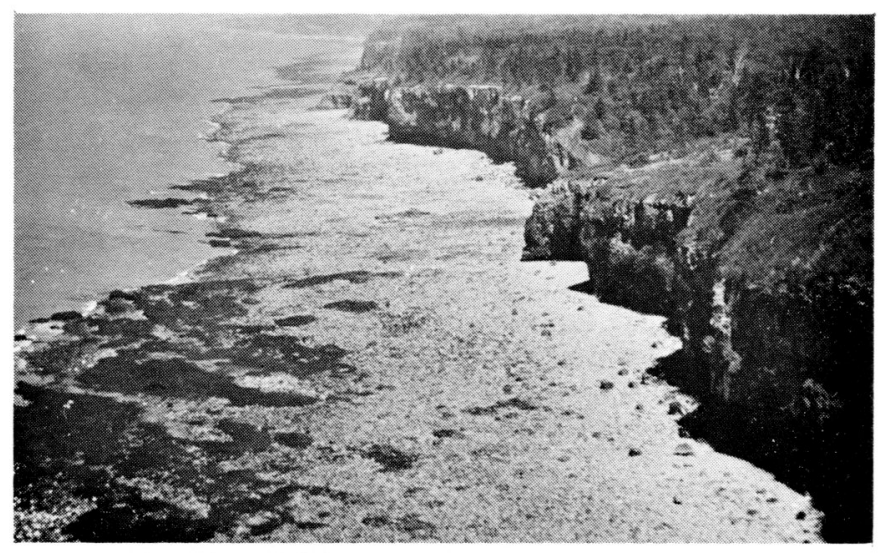

FIG.20 Intertidal platform mantled by cobble-boulder sediments, and resistant eroding cliffs, east of Digby, south shore Bay of Fundy (photo at low tide).

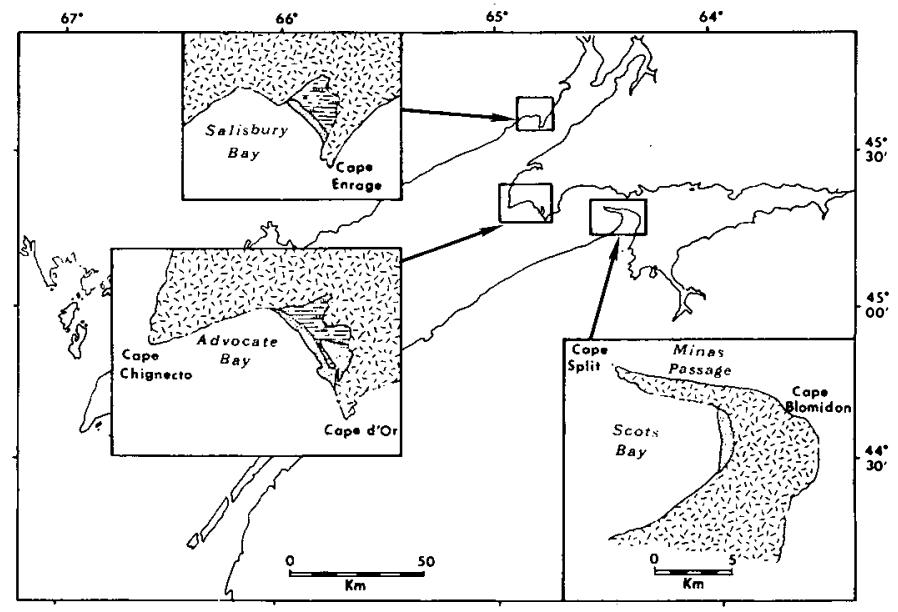

FIG. 21 Details of three large embayments in the Head of the Bay unit (from Owens, 1977b). 
resulted, but otherwise the coast is largely devoid of sediments. East of Digby Gut a wide rocky intertidal platform is backed by vertical cliffs up to $30 \mathrm{~m}$ in height. The upper intertidal zone has a discontinuous cover of coarse sediments (pebblecobble-boulder) (Fig. 20).
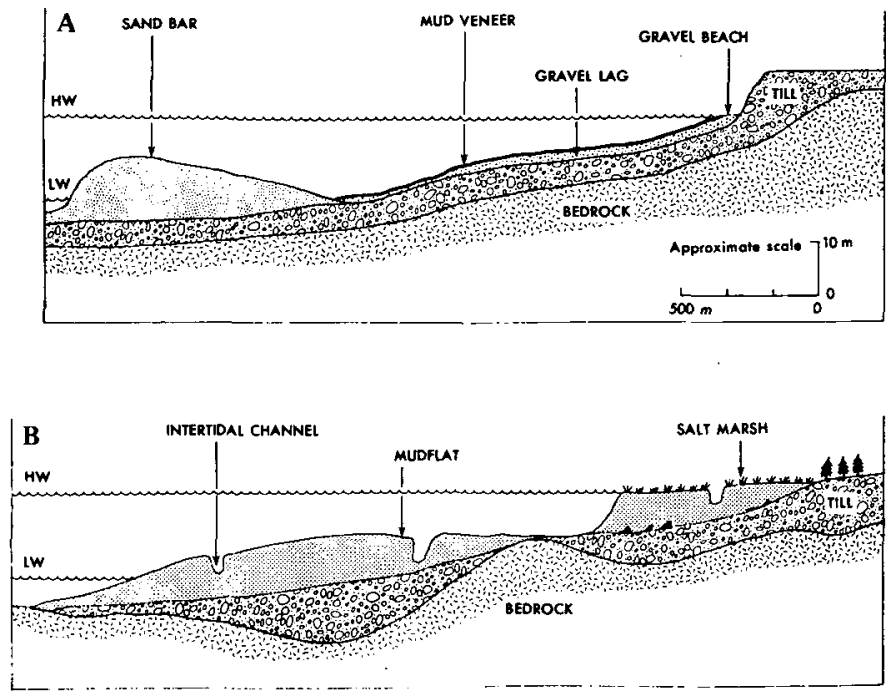

FIG. 22 Idealized profiles across two of the major shoreline types in the Minas Basin.

(A) Intertidal sand flats with a gravel beach at the HWM backed by an unresistant till cliff.

(B) Intertidal mud flats that give way to salt marshes above the HWM.

(Adapted from (A) Dalrymple et al., 1975 and (B) Swift et al., 1973).

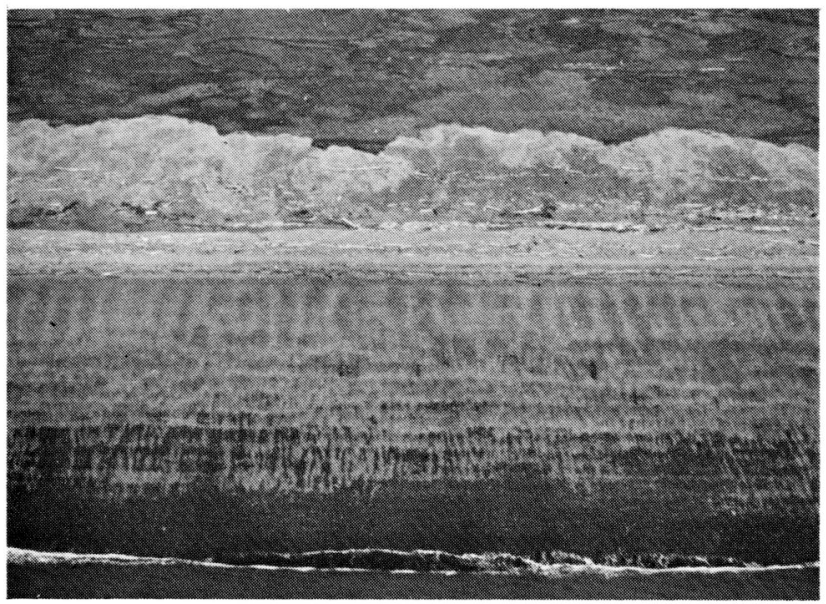

FIG. 23 Beach, storm ridge, overwash and marsh sequence at Advocate Harbour, N.S.
Head of the Bay

The Head of the Bay is considered a distinct unit on the basis of its exposed location with respect to waves generated along the axis of the Bay. Although primarily a coast of high resistant cliffs, this upland coast is also characterized by three large southwest-facing pocket beaches (Fig. 21). In the southeastern part of this unit the curved shape of the Cape Blomidon-Cape Split exposure of the eastern end of the Triassic basalt dyke results from the presence of the Fundy syncline, which runs west-east through Scots Bay (Swift and Borns 1967). In the central area, which separates Minas Basin. and Minas Channel from Chignecto Bay, the Cobequid Uplands, a zone of lower Paleozoic metamorphic and igneous rocks, gives way north to Permo-Carboniferous sedimentary rocks. The western extremity of this upland area is the resistant Devonian granite outcrop of Cape Chignecto (Fig. 3). Southeast of Cape Chignecto an extension of the Cape Split Triassic dyke forms a major headland at cap d'or. Between these two resistant headlands, Permo-Carboniferous sedimentary rocks associated with the Parrsboro fault block have been eroded to form the large embayment of Advocate Harbour. In the northern section of this unit the generally, straight coast is interrupted by a major headland at Cape Enragé that is an outcrop of resistant, vertically dipping Permo-Carboniferous conglomerates. Erosion along a northeasterly-southwesterly trending fault has produced the large embayment of Salisbury Bay by offsetting Cape Enragé from the otherwise straight coast. A fourth smaller embayment, located at Cape Capstan, has resulted from erosion by the Apple River along a structural weakness. As a result of either structural control or the nature and location of resistant outcrops, these large southwest-facing embayments have developed at the head of the Bay of Fundy.

In each case, these embayments are bounded by headlands or coasts of high cliffs and rocky intertidal platforms and act as large sediment traps for any material that is supplied to the littoral zone either by local erosion or by longshore transport. The Scots Bay-Cape Split embayment traps sediment that is moved to the northeast along the straight South Shore unit. Material is supplied to the Advocate Harbour embayment by erosion and reworking of the local sedimentary rocks and glacio-fluvial or fluvio-marine sediments. The Cape Capstan embayment traps sediment that is moved along the south shore of Chignecto Bay, and a midbay bar constricts the mouth of the Apple River. In the Salisbury Bay-Cape Enragé embayment sediments have accumulated by the trapping of material transported alongshore to the northeast and by the erosion of local unresistant sedimentary rocks.

Relief in the area is generally high; maximum cliff heights are $80 \mathrm{~m}$ at Cape Split, $180 \mathrm{~m}$ at Cape Blomidon, $150 \mathrm{~m}$ at Cap d'Or, $210 \mathrm{~m}$ at Cape Chignecto, and $35 \mathrm{~m}$ at Cap Enragé.

An initial marine overlap of 30 to $40 \mathrm{~m}$ after deglaciation was followed by emergency and final submergence to present sea level. Isobases trend almost north-south across the region, increasing 
from $20 \mathrm{~m}$ at Cape Split to $40 \mathrm{~m}$ at Advocate Harbour and approximately $43 \mathrm{~m}$ at Cape Enragé (Swift and Borns 1967). Interpretation of deposits in a large raised marine spit in the Advocate Harbour area, $42 \mathrm{~m}$ above present high-tide level; indicates that the maximum paleo-tidal range at the time this spit was formed was $3.4 \mathrm{~m}$ (Wightman 1976).

Mean and spring tidal ranges in this unit vary between 8.8 and $12.2 \mathrm{~m}$ at West Advocate, 9.5 and $13.2 \mathrm{~m}$ at Cape Enragé, and 10.7 and $14.4 \mathrm{~m}$ at Cape Blomidon (Fig. 19). Currents generated by the semi-diurnal tides are strong in the offshore zone $(>1 \mathrm{~m} / \mathrm{s})$ and decrease little in velocity with depth. Currents reach velocities in excess of $5 \mathrm{~m} / \mathrm{s}$ in the Minas Passage area (Cameron 1961). Prevailing and dominant winds are out of the westerly quadrant and coincide with the direction of maximum fetch, that is, along the axis of the Bay, so that the shoreline in this unit is exposed to the highest levels of wave energy in the Bay. As in all macrotidal environments, however, this energy is expended over a wide vertical range.

The coast is predominantly one of high $(>20 \mathrm{~m})$ resistant cliffs, but occasional wide intertidal rock platforms or small pocket beaches occur. Large embayments (Salisbury Bay, the Apple River estuary, Advocate Harbour, and Scots Bay) are sediment traps exposed toward maximum fetch directions; they have well-developed beaches and wide (1-2 km) mud lowtide terraces and steep pebble-cobble beach faces that are backed by storm ridges and by marshes (Fig. 22). Coarse-grained beaches occur at the base of the cliffs where talus deposits are reworked by littoral processes.

\section{Minas Basin}

Minas Basin is an extension of the Bay of Fundy, which trends eaterly owing to erosion along the Cobequid Fault, which defines the north shore of the Basin. The Carboniferous and Triassic rocks that outcrop around the Basin are unresistant red or grey sedimentary rocks and are eroding at a rate of approximately $0.5 \mathrm{~m} /$ year (Amos 1976). A few small outcrops of Triassic basalt occur in the Five Islands area, along the north shore. The. bedrock is overlain by till and outwash deposits, usually $<10 \mathrm{~m}$ thick. These glacial and fluvioglacial sediments occur mainly in bedrock lows along the shore (Swift and Borns 1967).

The marine limit of overlap following deglaciation decreases from 22 m near Parrsboro to zero at the eastern end of the Basin (Swift and Borns 1967) Sediment in the Minas Basin is derived largely from coastal erosion of the unresistant Carboniferous and Triassic rocks and the glacial deposits (Dalrymple et al 1975). Major intertidal sand bodies occur along the southern and northeastern margins of the Basin. Two major bodies in the south and east are located at the Avon River and at the head of Cobequid Bay (Swift and McMullen 1968). On the north shore two large sand bodies are located in the areas of Economy Point and Five Islands (Klein 1970). These sand bodies rest on till and (or) bedrock, are up to $25 \mathrm{~m}$ thick and are often exposed in the intertidal zone (Dalrymple et al 1975).
Tidal range in the Minas Basin reaches a maximum in the vicinity of Burncoat Head, where the mean and large ranges are given as 11.9 and $16.3 \mathrm{~m}$, respectively (Canadian Hydrographic Service 1975b). Everywhere within the Basin the mean tidal range of the semi-diurnal tides is greater than $10 \mathrm{~m}$. This large range leads to the generation of strong intertidal currents that reach velocities in the order of $2 \mathrm{~m} / \mathrm{s}$ (Knight and Dalrymple 1976). The Basin is oriented east-west, so that the maximum fetch direction coincides with the prevailing and dominant winds out of the westerly quadrant. Wave heights in summer are usualiy in the order of 0.5 to $1 \mathrm{~m}$, but occasional storm waves reach $2 \mathrm{~m}$ in height (Knight and Dalrymple 1976). Littoral processes are dominated by tide-generated currents.

Ice plays an important role in limiting tidal and wave action from late December to early April. Although the sea ice does not form a solid sheet, the ice cover is 70 to $90 \%$ (Knight and Dalrymple 1976). On the coast an ice foot develops that is 1 to $2 \mathrm{~m}$ high and 10 to $30 \mathrm{~m}$ wide on gently sloping intertidal zones, but can reach $9 \mathrm{~m}$ in height on steeply sloping bedrock coasts (Knight and Daleymple 1976). Considerable quantities of sediment are redistributed by ice-rafting as broken sea ice grounds and is re-floated by the semi-diurnal tides.

The coastal geomorphology of this unit is characrerized by large intertidal sand or mud deposits (Fig. 23). The characteristic sequence (Fig. 24a) has a pebble-cobble beach near the highwater mark that gives way seaward to a gravel lag deposit that has a thin $(15 \mathrm{~cm})$ mud veneer. This lag deposit in turn is replaced by a large sand deposit, up to $5 \mathrm{~km}$ wide, in the middle and lower intertidal zone (Dalrymple et al 1975). The sand flats are characterized by surface sand waves and megaripples that are formed by the high-velocity tidal currents (Fig. 25). Toward the east and in areas sheltered from the strong tidal currents (bays and estuaries), the intertidal sand is replaced by mud flats as fine-grained sediments are deposited following a decrease in tidal-current velocities. The backshore is either bedrock cliffs, which can reach $30 \mathrm{~m}$ in height, Pleistocene deposits, or salt marsh (Fig. 24b). The marshes are incised by deep muddy creeks that have little or no vegetation. In areas not dyked by man the marsh association is either Spartind patens that is near its northern limit, or Spartina alterniflora (Chapman 1960). The marshes are particularly extensive in the eastern section of Cobequid Bay. The cliffed sections of this coast usually have a beach of reworked talus deposits; sediments are in the sand- to boulder-size range.

\section{Chignecto Bay}

Erosion along southwest-northeast structural trends (Fig. 3) has produced Chignecto Bay, the northern arm of the inner Bay of Fundy. The bedrock is unresistant Permo-Carboniferous sedimentary rocks that form cliffs up to $20 \mathrm{~m}$ high along the coast. Following deglaciation the area was submerged, so that at the head of Cumberland Basin a strait linked the southern Gulf of St. Lawrence with the Bay of Fundy. Following emergence and establishment of the isthmus that connects Nova Scotia to 

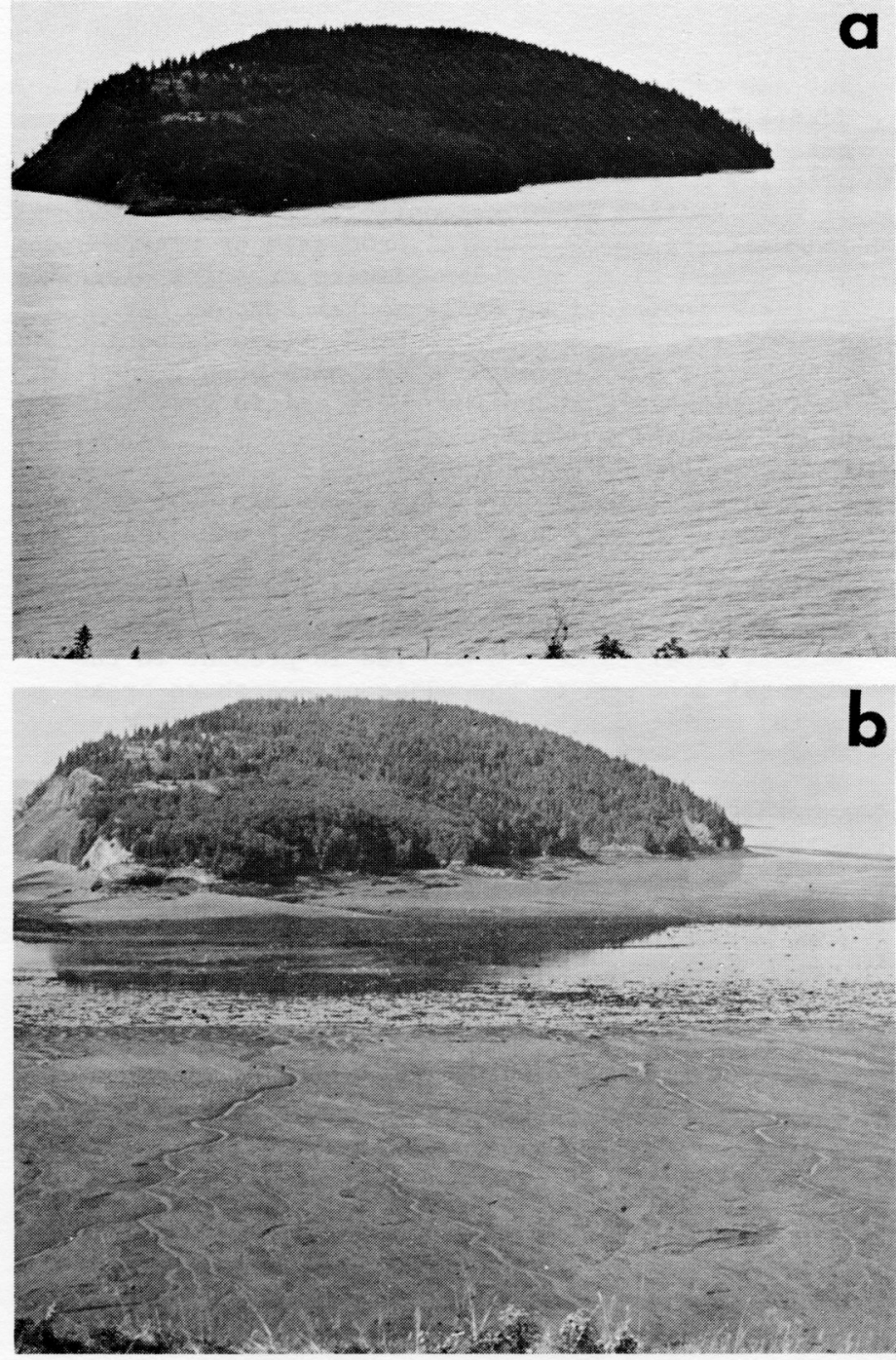

FIG. 24 Five Islands, Minas Basin at (a) high and (b) low tide.

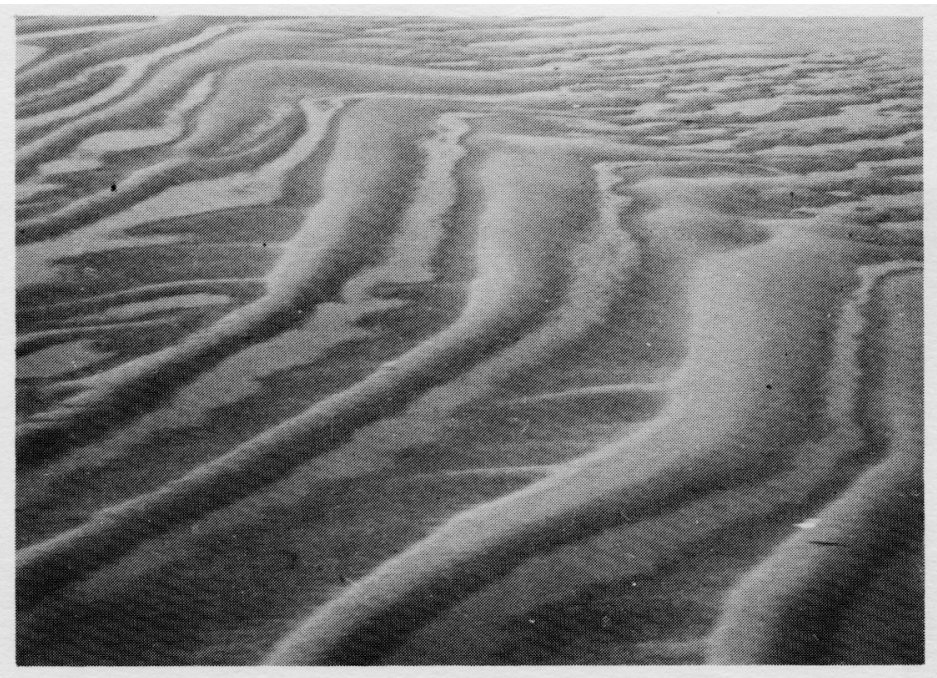

FIG. 25 Intertidal sand waves exposed of low tide near the Avon River estuary, Minas Basin. the mainland, sea level has been rising at a rate of $30 \mathrm{~cm} /$ century over the past 4,000 years (Grant 1970). Erosion of coastal outcrops of glacial deposits and the unresistant sedimentary rocks provides sediment directly to the littoral zone for reworking and redistribution. The intertidal sediments in this unit are mainly muds, as compared with the large volumes of sand on the exposed intertidal flats of the Minas Basin. Beaches of coarse sediments (pebble-cobble-boulder) occur in the upper part of the intertidal zone.

The semi-diurnal tides are everywhere greater than $10 \mathrm{~m}$ and reach a maximum at the heads of Shepody Bay and Cumberland Basin; mean ranges are $11.8 \mathrm{~m}$ and large ranges are $14.5 \mathrm{~m}$ (Canadian Hydrographic Service 1975b). This is a sheltered wave environment except for waves generated locally by winds out of the southwest, which is the maximum fetch direction. As in the Minas basin, wave heights are rarely greater than $2 \mathrm{~m}$ and the available wave energy is dissipated over a considerable vertical range, so that littoral processes are dominated by the effects of the tides. Sea and beach-fast ice are present from December to early April. The sea ice cover is less than in the Minas Basin, as Chignecto Bay is more open and ice floes are moved easily into the main body of the Bay of Fundy by the ebbing tide and by winds out of the northeast. Ice plays an important role in. redistributing sediments and vegetation by rafting these materials during winter months, particularly in the upper part of the Bay.

The coast of this unit is primarily one of wide (up to $2 \mathrm{~km}$ ) intertidal rock platforms backed by unresistant cliffs. The platforms are covered by extensive mud deposits dissected by tidal

channels that in sheltered areas give way to extensive marshes. The marsh sediments are red inorganic muds that contain little or no riverborne material, but result from deposition during spring tides and storm surges (Ganong 1903). The marshes are not flooded by ordinary tides, and Ganong describes them as the "flood plains of tidal rivers." The most extensive marshes are at the head of Cumberland Basin (Tantramar-Aulac; Missaquash; and La Planche). Other large marshes are in Shepody Bay (Memramcook River; Petitcodiac River; and Shepody River). Most of the marshes have been dyked during historical times, so that only some 4,000 hectares remain in their natural condition. Thickness of the sediments varies, but is usually in the order of 6 to $10 \mathrm{~m}$. At Aulac a sequence of $24.4 \mathrm{~m}$ of mud and $6.1 \mathrm{~m}$ of freshwater peat overlies the pleistocene clays (Chalmers 1896). Submerged forests: are present at the base of the marsh sediments at various localities; an outcrop at Fort Beausejour is $11.5 \mathrm{~m}$ below the present marsh surface and has been dated at 4,010 \pm 130 years B.P. (Grant 1970).

North Shore

The North. Shore, a straight section along the north-central coast, is a dissected, fault-line scarp shoreline lying (Johnson 1925) between precambrian crystalline rocks to the north, and the unresistant Triassic sedimentary rocks that underlay the offshore area. Structural trends through- 


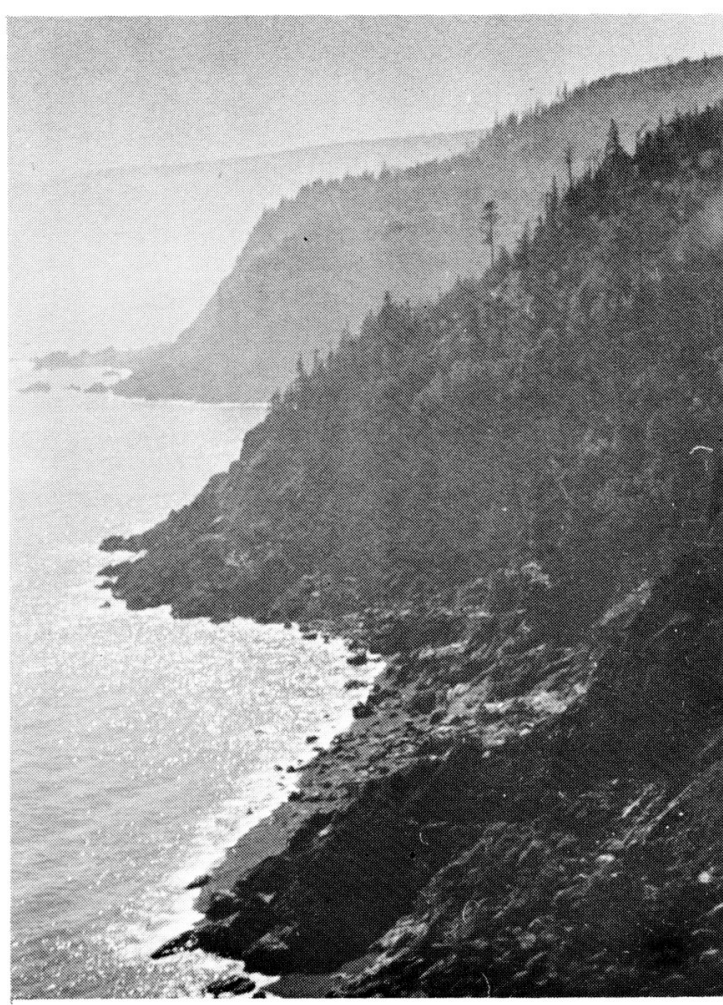

FIG. 26 Upland coast, Fundy National Park.
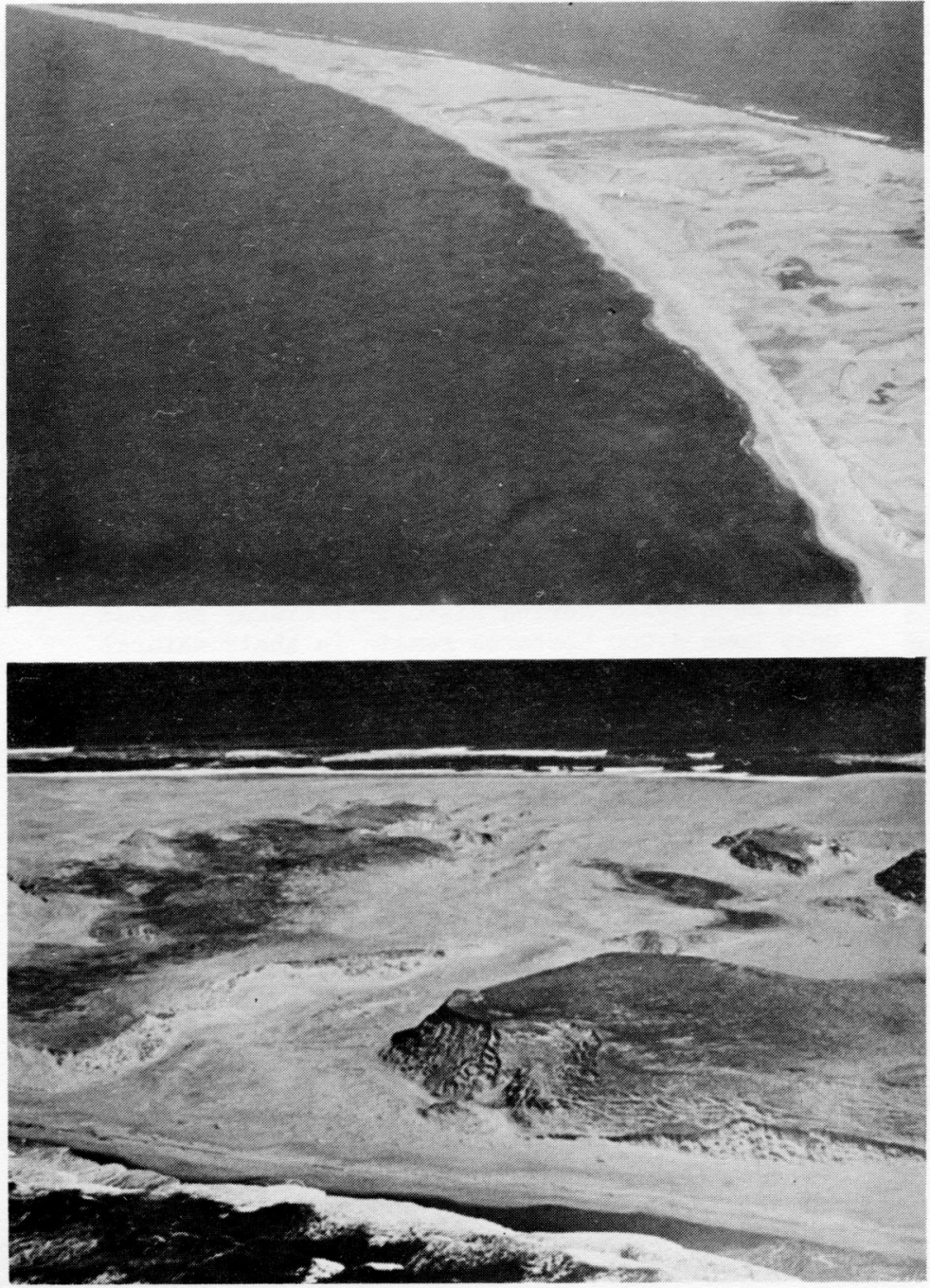

out the region are northeast-southwest (Hayes and Howell 1937). East of Quaco Head the straight resistant upland coast is characterized by cliffs over $100 \mathrm{~m}$ in height (Fig. 26). The homogeneity of this section is occasionally interrupted by indentations where littoral processes or rivers have eroded along secondary faults or joint planes. In these indentations small pocket beaches have accumulated. West of Quaco Head, Permo-Carboniferous sedimentary and intrusive rocks have been eroded to form a crenulate shoreline where cliffs vary in height from 51 to $60 \mathrm{~m}$.

Mean tidal range (Fig. 19) increases from $5.7 \mathrm{~m}$ at Saint John to $9.0 \mathrm{~m}$ near Salisbury Bay, and spring tidal ranges increase from $9.1 \mathrm{~m}$ to $11.9 \mathrm{~m}$. The coast is exposed to winds and locally generated waves out of the south and southwest, but wave heights rarely exceed $4 \mathrm{~m}$. Ice is present in the littoral zone and on the adjacent nearshore areas during winter months, but the beach-fast ice may thaw and freeze periodically. The character of the coast is determined primarily by geologic and physiographic parameters; 1ittle sediment is available for reworking and redistribution and the only major accumulations are at the Alma River, Martin Head and in Quaco Bay. Elsewhere, the narrow hightide beaches consist of coarse-grained sediments (pebble-cobble-boulder).

FIG. 27 The eastern end of Sable Island.

FIG. 28 Close-up view across the east end of Sable Island, view to the south. 


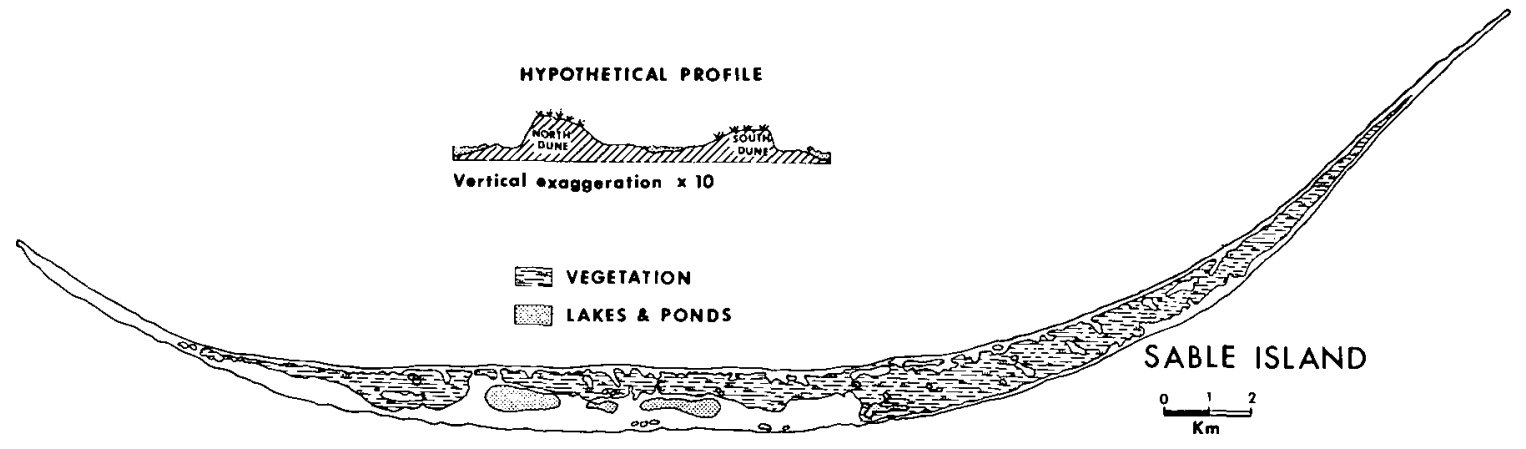

FIG. 29 Sable Island, with hypothetical profile across the central part of the Island (after James and Stanley, 1967).

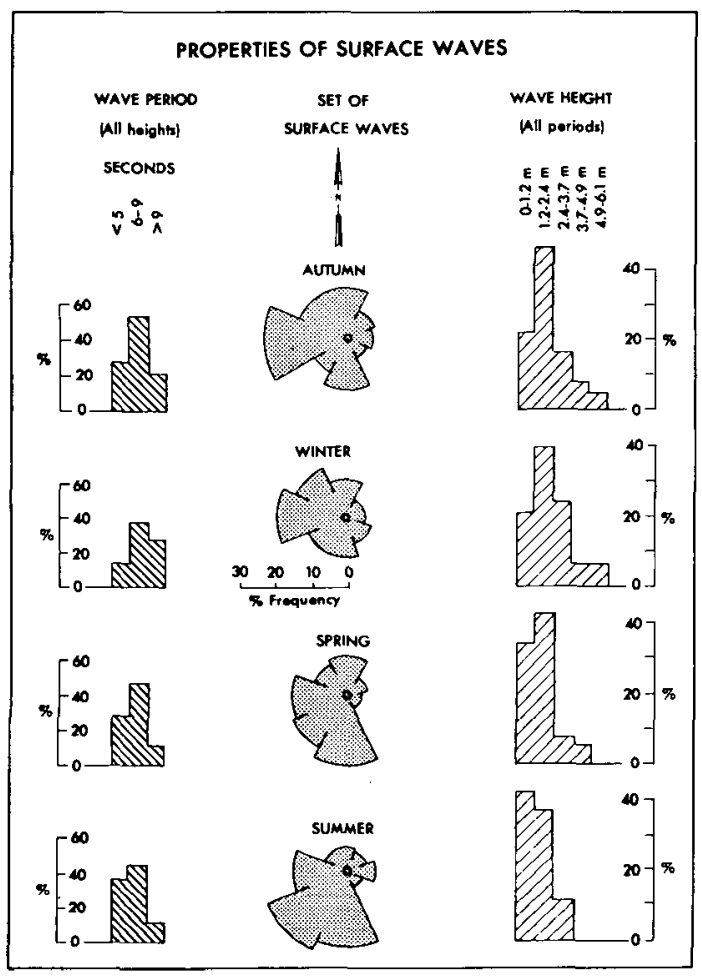

FIG. 30 Wave period, direction and height data for the Sable Island area (adapted from James and Stanley, 1967).
Northwest Shore

The drowning of the low-lying Northwest Shore region has produced a complex shoreline of bays, inlets and islands. The rocks are resistant and Precambrian to Devonian in age, and small outcrops of Triassic intrusives are found on north Grand Manan and at Point Lepreau. The structural trends are southwest-northeast and have a noticeable influence on local shoreline configuration. The west and southeast shores of Grand Manan are fault-line coasts. Cliffs on the west-facing coast of Grand Manan reach $100 \mathrm{~m}$ in height, but elsewhere in this unit cliff heights rarely exceed $15 \mathrm{~m}$. Surficial sediments are usually thin $(<10 \mathrm{~m})$ as this is an area of resistant rocks. Occasional thick deposits occur locally, for example, the Point Lepreau moraine. Littoral sediments are generally scarce, as little material is supplied to the coast from erosion of the resistant cliffs or of the scarce coastal outcrops of glacial sediments.

This coast became ice-free about 16,500 years B.P., at which time sea level was below its present level (Gadd 1973). About 13,500 years B.P. the subsequent slow submergence resulted in a marine overlap of $.73 \mathrm{~m}$. Rebound and emergence has since been followed by a transgression that drowned the low-lying terrain.

The outer coasts are exposed to waves entering the Bay of Fundy from the Gulf of Maine. However, due to the complex shoreline much of this unit is characterized by sheltered low-energy wave environments. Tidal ranges are on the order of 5 to $7 \mathrm{~m}$ (Fig. 19), so that even on the exposed coasts this is still. a tide-dominated macrotidal environment. Tidal currents parallel the coast from northeast to the southwest, following the 
main direction of the ebb currents (Swift et al 1973). Tidal currents are particularly strong in Grand Manan Channel (up to $2 \mathrm{~m} / \mathrm{s}$ ) (Canadian Hydrographic Service 1975b) and at the entrance to Passamaquoddy Bay $(>1 \mathrm{~m} / \mathrm{s})$ (Pelletier 1974). In winter months sea ice develops and is present in the bays and inlets for periods up to 4 months each year.

The eastern part of this unit is an indented coast; the sheltered embayments of St. John's. Harbour, Lorneville Harbour, Musquash Harbour and Maces Bay are separated by the exposed, low, resistant headlands of Lorneville, Seely Point and Point Lepreau (up to $30 \mathrm{~m}$ in height). Sediments have accumulated in the embayments to produce wide mud flats in the lower intertidal zone. The mud flats give way to a pebble-cobble beach in the upper intertidal zone, and the beach is backed by marshes. Beaches are generally narrow and have coarse sediments in the gravel and boulder size range. West of Maces Bay, the large re-entrant of Passamaquoddy Bay has a complex rocky coast of islands and bays. The entrance to Passamaquoddy Bay is partially closed by Campobello Island and Deer Island, to give a sheltered low-energy wave environment. Few beaches occur in this section and little marsh development has occurred owing to the lack of fine-grained sediments. Grand Manan Island lies $11 \mathrm{~km}$ off the mainland coast and comprises an upland area of resistant Triassic intrusives. The northwest coast is a fault scarp, whereas the east coast has become a small archipelago of low rocky islands with the recent submergence of this region. The east coast of the island has some well-developed sand beaches that are separated by rocky cliffs.

\section{SABLE ISLAND}

Sable Island is a small sand deposit that lies approximately $200 \mathrm{~km}$ southeast of the mainland coast of Nova Scotia on the outer margin of the Scotian shelf. This depositional remnant is composed entirely of unconsolidated sands. It is arcuate in shape (Fig. 27), oriented west-east, and is $37 \mathrm{~m}$ long with a maximum width of $1.5 \mathrm{~km}$ (Fig. 28). Dune heights are on the order of 5 to $15 \mathrm{~m}$ with a maximum elevation of $26 \mathrm{~m}$. The island is composed of glacial and fluvio-glacial sediments that have been reworked and redistributed by waves, currents and winds during the post-glacial rise in sea level. The sands are in the medium sandsize range and are generally very well sorted, particularly on the south shore (James and Stanley 1967). The island is characterized by two dune ridges that parallel the north and south coasts (Fig. 29). The dunes have been destroyed in the southwestern section during historical times (since the 1850s), and the adjacent flat inland areas are regularly inundated during storms.

The winds in this microtidal area (range: 1.1 to $1.6 \mathrm{~m}$ ) have a distinct seasonal variability: strong northeast winds in winter (mean velocity $30 \mathrm{~km} / \mathrm{h}$ ) and gentler southwest winds in summer months (mean velocity $20 \mathrm{~km} / \mathrm{h}$ ). (Fig. 5, Table 6). The higher overall levels of wave energy on the north shore produce a beach that is both narrower and steeper than that on the south-facing coast.
The seasonal change in wind direction and velocity is reflected in the characteristics of the surface waves that approach Sable Island (Fig. 30) (see also Halifax: Table 8). As the prevailing directions of wave approach are from the west to northwest in winter and south to southwest in summer, sediment transport in the littoral zone is primarily to the east. James and stanley (1968) suggest that there is a cyclical movement of sediment around the island with erosion in winter months and a subsequent shoreward transport. The sediment dispersal pattern in the littoral and adjacent offshore zones results, therefore, from a combination of wave- and tide-induced currents.

Cameron (1965) determined that the west end of the island was eroded $14.5 \mathrm{~km}$ in the last 200 years while the east end has accreted $17.7 \mathrm{~km}$. It appears, therefore, that the island is not being reduced in size at the present but rather is migrating slowly eastward on the shallow shelf (James and Stanley 1967). Superimposed on the long-term natural changes is a contemporary erosion of the dune systems by eolian and storm-wave processes. This erosion can be partially attributed to man's use of the island since the sixteenth century, and restoration attempts are currently in progress to reduce the adverse effects of erosion in some of the more seriously endangered parts of the island (Owens 1975b).

\section{CONCLUSIONS}

The regional morphology of the coastal zone of the Maritime Provinces can be related to the southwest-northeast structural trends and to local geology and relief. There is, however, a great contrast between the resistant rocky coasts of the Bay of Fundy and Atlantic Nova Scotia and the younger, less resistant sandstones of the southern Gulf of st. Lawrence. It is this great variability, both in coastal morphology and in shoreline processes, within a relatively small geographical area that is the major characteristic of this region.

Tidal range varies from 1 to $16 \mathrm{~m}$, and wave energy levels are high on the exposed Atlantic coasts but are very low in sheltered environments such as Chignecto Bay and Northumberland Strait. Geological formations range in age from Precambrian to the Triassic. The actual form of the coastline varies from straight fault-line coasts (northern Minas Basin, and southern Chedabucto Bay) to complex crenulate drowned lowland coasts (northern Chedabucto Bay and Passamaquoddy Bay). Shoreline types vary from resistant vertical cliffs where there are no beaches to larger barrier island systems, marshes or extensive intertidal mud and sand flats.

The approach presented in this review provides a useful and practical framework for the definition and description of coastal environments. This method of identification of homogeneous units can be applied at both larger and smaller scales (e.g. all of Canada or the Bay of Fundy) but is particularly useful in the Maritime Provinces region, where there is such a high degree of variability in coastal processes and morphology. 


\section{ACKNOWLEDGMENTS}

Field studies in the Maritime Provinces carried out by the authors were made possible by a number of agencies. Studies in the Gulf of St. Lawrence (EHO) were part of a series of investigations at the Atlantic Geoscience Centre, Bedford Institute, Dartmouth, Nova Scotia. The Province of Nova Scotia supported a study of the shoreline characteristics of the entire province (AJB). A reconnaissance of Chedabucto Bay (EHO) was undertaken as part of "Project Oil" following the spill from the tanker ARROW, and a reconnaissance of the Bay of Fundy coast (EHO) was carried out for the Environmental Protection Service of Environment Canada in Halifax. Salary support (EHO) during preparation of this paper was provided by the Geography Programs, Office of Naval Research, Arlington, Virginia, 22217 under a contract with Coastal Studies Institute, Louisiana state University.

\section{REFERENCES}

AMOS, C.L. 1976. Suspended sediment analysis of seawater using LANDSAT imagery, Minas Basin, Nova Scotia; Geol. Surv. Can., Paper 76-IC, pp. 55-60.

ARMON, J.W. 1975. The dynamics of a barrier island chain, Prince Edward Island, Canada; Unpubl. Ph.D. thesis, McMaster Univ., 546 pp.

BOWEN, A.J., EDMOND, D.P., PIPER, D.J.W. and WELSH, D.A. 1975. The maintenance of beaches; Inst. of Environmental Studies, Dalhousie University, Halifax, Technical Report, $582 \mathrm{pp}$.

BRYANT, E.A. 1972. The barrier islands of Kouchibouguac Bay, New Brunswick; Unpubl. M.Sc. thesis, McMaster Univ., 277 pp.

BRYANT, E.A. and MCCANN, S.B. 1972. A note on wind and wave conditions in the southern Gulf of St. Lawrence; Maritime Sediments, v. 8 (3), pp. 101-103.

BRYANT, E.A. and MCCANN, S.B. 1973. Long and short term changes in the barrier islands of Kouchibouguac Bay, southern Gulf of St. Lawrence; Can. J. Earth Sci., v. 10, pp. 1582-1590.

CAMERON, H.L. 1961. Interpretation of high altitude, small-scale photography; Can. Surveyor, v. 15, pp. 567-573.

CAMERON, H.I. 1965. The shifting sands of Sable Island; Geogr. Rev., 55 (4), pp. 463-476.

Canada, Department of Transport 1968. Climatic normals; v. 5, Wind; Meteorological Branch, Toronto, $95 \mathrm{pp}$.

Canadian Hydrographic Service. 1975a. Canadian tide and current tables, 1976; v. 2, Gulf of St. Lawrence; Environment Canada, Ottawa, $67 \mathrm{pp}$.

1975b. Canadian tide and current tables, 1976; v. 1, Atlantic Coast and Bay of Fundy; Environment Canada, Ottawa, $83 \mathrm{pp}$.
Canadian Hydrographic Service 1976, Sailing directions, Nova Scotia (SE coat) and Bay of Fundy; Dept. of the Environment, Ottawa, 7th edition, $283 \mathrm{pp}$.

CHALMERS, R. 1896. Report of the surface geology of eastern New Brunswick, north-western Nova Scotia, and a portion of Prince Edward Island; Geol. Surv. Can., Ann. Rept. v. 7, 1894, part M, $149 \mathrm{pp}$.

CHAPMAN, V.J. 1960. Salt marshes and salt deserts of the world; Leonard Hill, London, $392 \mathrm{pp}$.

CHURCHILL, F.J. 1924. Recent changes in the coatline in the County of Kings; Proc. and Trans. Nova Scotia Inst. Sci., v. 16, pp. 84-86.

CROWL, G.H. 1969. Geology of Mount Stewart - Souris map area, Prince Edward Island; Geol. Surv. Can., Paper 67-66, 26 pp.

DAVIES, J.L. 1964. A morphogenic approach to world shorelines; Zeits. Geomorphol., v. 8, Mortensen Sonderheft, pp. 127-142.

DALRYMPLE, R.W., KNIGHT, R.J . and MIDDLETON, G.V. 1975. Intertidal sand bars in Cobequid Bay (Bay of Fundy): in L.E. Cronin (ed.) Estuarine Research, v. 2, Academic Press, N.Y., pp. 293307.

DAVIDSON-ARNOTT, R.G.D. and GREENWOOD, B. 1976. Facies relationships and barred coast, Kouchibouguac Bay, New Brunswick, Canada; in R.A. Davis, Jr. and R.L. Ethington (eds.) Beach and Nearshore Sedimentation, Soc. Econ. Paleon. and Mineral., Spec. Publ. No. 24, pp. 149-168.

FARQUHARSON, W.I. 1959. Causeway investigation Nor thumberland Strait; Report on Tidal Survey, 1958, Can. Dept. Energy, Mines and Resources, Surveys and Mapping Branch, 137 pp.

FORWARD, C.N. 1960a. Shoreline changes in Egmont Bay and Bedeque Bay, Prince Edward Island; Can. Dept. Mines and Tech. Surv., Geogr. Branch, Paper 26, $15 \mathrm{pp}$.

1960b. Shorelines of Northumberland Strait, Geogr. Bull. No. 14, pp. 100-105.

FRANKEL, L. and CROWL, G.H. 1961. Dxowned forests along the eastern coast of Prince Edward Island, Canada; J. Geol., 69 (3), pp. 352-357.

GADD, N.R. 1973. Quaternary geology of southwest New Brunswick with particular reference to Fredericton area; Geol. Surv. Can., Paper 71-34, $31 \mathrm{pp}$.

GANONG, W.F. 1903. The vegetation of the Bay of Fundy salt and diked marshes: an ecological study; Bot. Gaz., 36, pp. 161-186, 280-302, 349-367, and $429-455$.

GANONG, W.F. 1908. The physical geography of the north shore sand islands; Bull. New Brunswick Nat. Hist. Soc., no. XXVI, v. VI, pt. 1, pp. 22-29. 
GRANT, D.R. 1970. Recent coastal submergence. of the Maritime Provinces; Canada; Can. J. Earth Sci., v. 7, pp. 676-689.

1971a. -Glaciation of Cape Breton Island, Nova Scotia; Geol. Surv. Can., Paper 71-1, Part B, pp. 118-120.

1971b. Glacial deposits, sea level changes and pre-Wisconsin deposits in southwest Nova Scotia; Geol. Surv. Can., Paper 71-1, Part B, pp. 110-113.

1972. Maritime sea-level changes: and glacial events; 24 th. Int. Geol. Congr., Field Excursion A61-C61 Guidebook, pp. 10-23.

1974. Terrain studies of Cape Breton Island, Nova Scotia and the Northern Peninsula, Newfoundland; Geol. Surv. Can., Paper 74-1, Part A, pp. 241-246.

1976. Late Wisconsin ice limits in the Atlantic Provices of Canada with particular reference to Cape Breton Island, Nova Scotia; Geol. Surv. Can., Paper 76-1C, pp. 289-292.

GREENWOOD, B. and DAVIDSON-ARNOTT, R.G.D. 1975. Marine bars and nearshore sedinentary processes, Kouchibouguac Bay, New Brunswick, Canada; in J.R. Hails and A. Carr (eds.) Nearshore Sediment Dynamics and Sedimentation. John Wiley and Sons, New York, pp. 123-150.

HAYES, A.O., and HOWELL, B.F., 1937. Geology of Saint John, New Brunswick; Geol. Soc. Amer. Spec. Paper No. 5, $146 \mathrm{pp}$.

JAMES, N.P. and STANLEY, D.J. 1967. Sediment transport on Sable Island, Nova Scotia; Smithsonian Misc. Coll., 152 (7), Publ. 4723, 33 pp.

1968, Sable Island Bank off Nova Scotia: Sediment dispersal and recent history; Amer. Assoc. Petr. Geol. Bull., 52 (11), pp. $2208-2230$.

JOHNSON, D.W. 1925. The New England Acadian shoreline; Wiley and Sons, N.Y., 608 pp. (Facsimile Ed.: Hafner, N.Y., 1967).

KLEIN, G. deV. 1963. Bay of Fundy intertidal zone sediments; s. Sed. Petrol., v. 33, pp. 844-856.

1970. Depositional and dispersal dynamics of intertidal sand bars:; J. Sed. Petrol., v. 40, pp. 1095-1127.

KNIGHT, R.J. and DALRYMPLE, R.W. 1976. Winter conditions: in a macrotidal environment, Cobequid Bay, Nova Scotia; Rev. Geogr. Montr., 30 (1-2). pp. 65-85.

KRANCK, K. 1971. Surficial geology of Northumberland Strait; Geol. Surv. Can., Paper 71-53, 10 pp.

1972a. Geomorphological developments and post-Pleistocene sea-level changes, Northumberland Strait, Maritime Provinces; Can. J. Earth Sci., v. 9, pp. 835-844.
KRANCK, K. 1972b. Tidal current control of sediment distribution in Northumberland Strait, Maritime Provinces; J. Sed. Petrol., v. 42, pp. 596-601.

LORING, D.H. and NOTA, D.J.G. 1973. Morphology and sediments of the Gulf of St. Lawrence; Fish Res. Board Can., Bull. no. 182, 147 pp.

MCCANN, S.B. 1972. Reconnaissance survey of Hog Island, Prince Edward Island; Maritime Sediments, v. 8, pp. 107-113.

MCCANN, S.B. and BRYANT, E.A. 1973. Beach changes and wave conditions, New Brunswick; Proceedings 13th Conference Coastal Engineering, Vancouver, B.C., (Am. Soc. Civ. Eng., N.Y.), pp. 12931304 .

MCINTOSH, D.S. 1919. Port Hood harbour, its past, present and probable future; Proc. Nova Scotia Inst. Sci., (15), 71.

MIDDLETON, G.V. 1972. Brief field guide to intertidal sediments, Minas Basin, Nova Scotia; Maritime Sediments, v. 8 (3), pp. 114-122.

MUNROE, H.D. 1976. The effects of storms on nearshore morphology, Neguac, New Brunswick; Geol. Surv. Can., Paper 76-1C, pp. 37-39.

NEELY, R. 1975. Observed and predicted longshore currents on Martinique Beach: A comparison of driving terms; Unpubl. M.Sc. thesis, Dalhousie University.

NEU, H.J.A. 1971. Wave climate of the Canadian Atlantic coast and continental shelf - 1970; Atlantic Oceanogr. Lab., Bedford Inst., Rept. 1971-10, $172 \mathrm{pp}$.

1972. Extreme wave height distribution along the Canadian Atlantic coast; Ocean Industry, July, pp. 45-49.

OWENS, E.H. 1971. A reconnaissance of the coastline of Chedabucto Bay, Nova Scotia; Mar. Sci. Paper No. 4, Dept. of the Environment, Ottawa, $24 \mathrm{pp}$. and map.

1974a. A framework for the definition of coastal environments in the southern Gulf of St. Lawrence; in: Offshore Geology of Eastern Canada (B.R. Pellètier, ed.); Geol. Surv. Can., Paper 74-30, v. 1, pp. 47-76.

1974b. Size analysis data of surface samples from the coastal zone of the southern Gulf of St. Lawrence; Bedford Inst. Oceanogr.,. Data Rept. BI-D-74-1, 106 pp.

1975a. Barrier beaches and sediment transport in the southern Gulf of St. Lawrence, Canada; Proc., 14th Int. Conf. Coastal Eng., Copenhagen, June 1974 (Amer. Soc. Civil Eng., New York, ), pp. 1177-1193.

1975b (ed.) Terrain Management Activities on Sable Island, 1975; Canadian Wildlife Service, Sackville, New Brunswick, $85 \mathrm{pp}$. 
OWENS, E.H. 1976. The effects of ice on the littoral zone, Richibucto Head, eastern New Brunswick. Rev. Geogr. Montr., 30 (1-2), pp. 95-104.

1977a. Coastal environments of Canada: The impact and cleanup of oil spills; Environment Canada, Environmental Protection Sexvice, Ottawa, Economic and Tech. Review, Rept. EPS3-EC-77-13, $413 \mathrm{pp}$.

1977b. Coastal environments oil spills and clean-up programmes in the Bay of Fundy; Environment Canada, Environmental Protection Service, Ottawa, Economic anä Tech. Review, Rept. EPS-3-EC-77-9, 175 pp.

1977c. Temporal variation in beach and nearshore dynamics; Jour. Sed. Petrol., $74(1)$, pp. 168-190.

OWENS, E.H. and DRAPEAU, G. 1973. Changes in beach profiles at Chedabucto Bay, Nova Scotia, following large-scale removal of sediments; Can. Jour. Earth Sci., 10 (8), pp. 1226-1232.

OWENS, E.H. and HARPER, J.R. 1972. The coastal geomorphology of the southern Gulf of St. Lawrence: a reconnaissance. Maritime Sediments 8 (2), pp. 61-64.

OWENS, E.H. and RASHID, M.A. 1976. Coastal environments and oil spill residues in Chedabucto Bay, Nova Scotia; Can. Jour. Earth Sci., 13 (7), pp. 908-928.

PALMER, A.J.M. 1974. Diatom stratigraphy and postglacial history of Basin Head Harbour, Prince Edward Island; Unpubl. M.Sc. thesis, Dalhousie Univ., $143 \mathrm{pp}$.

PELLETIER, B.R. 1974. Sedimentary textures and relative entropy and their relationship to the hydrodynamic environment, Bay of Fundy system; in: Offshore Geology of Eastern Canada (B.R. Pelletier, ed.), Geol. Surv. Can. Paper 74-30, v. 1, pp. 77-95.

PLOEG, J. 1971. Wave climate study, Great Lakes and Gulf of st. Lawrence; Nat. Res. Council Canada, Mech. Engin. Rept., vol. I, MH-107A, $160 \mathrm{pp}$.

PREST, V.K. 1962. Geology of the Tignish maparea, Prince County, Prince Edward Island; Geol. Surv. Can., Paper 61-28, 15 pp.

1970. Quaternary geology of Canada; in Geology and Economic Minerals of Canada, 5th ed., R.J.W. Douglas, ed.; Geol. Surv. Can., Econ. Geol. Rept. no. 1, pp. 676-758.

1973. Surficial deposits of Prince Edward Island; Geol. Surv. Can., Map 1366A.

PREST, V.K. and GRANT, D.R. 1969. Retreat of the last ice sheet from the Maritime Provinces Gulf of St. Lawrence region; Geol. Surv. Can., Paper 69-33, $15 \mathrm{pp}$.
REINSON, G.E. 1976. Channel and shoal morphology in the entrance to the Miramichi Estuary, New Brunswick; Geol. Surv. Can. Paper 76-1C, pp. 33-35.

SCHWARTZ, M.L. 1967. Littoral zone tidal-cycle sedimentation; J. Sed. Petrol., 37 (2), pp. 677683.

STEPHENSON, T.A., and STEPHENSON, A. 1954. Life between the tide-marks in North America, Part III - Nova Scotia and Prince Edward Island; J. Ecol., v. 42, pp. 14-70.

SWIFT, D.J.P. and BORNS, H.W. 1967. A raised fluviomarine outwash terrace, north shore of the Minas Basin, Nova Scotia; J. Geol., v. 75, pp. 693-710.

SWIFT, D.J.P. and MCMULLEN, R.M. 1968. Preliminary report on intertidal sand bodies in the Minas Basin, Bay of Fundy; Can. J. Earth Sci., 5 (2), pp. 175-183.

SWIFT, D.J.P., PELLETIER, B.R. LYALI, A.K. and MILLER, J.A. 1973. Quaternary sedimentation in the Bay of Fundy; in Earth Science Symp. on Offshore Eastern Canada (ed. P.J. Hood), Geo1. Surv. Can., Paper 71-23, pp. 113-151.

THOMAS, M.L.H., GRANT, D.R. and deGRACE, M. 1973. A late Pleistocene marine shell deposit at Shippegan, New Brunswick; Can. Jour. Earth Sci., v. 10, pp. 1329-1332.

WELSTED, J.E. 1974. Morphological maps of the Fundy coast; Maritime Sediments,v. IO(2), pp. 46-51.

WIGHTMAN, D.M. 1976. The sedimentology and paleotidal significance of a late Pleistocene raised beach, Advocate Harbour, Nova Scotia; Unpubl. M.Sc. thesis, Dalhousie Univ., Halifax, 157 pp.

ZIMLICKI, L.M. and WELSH, D.A. 1975. Literature survey for the Terrain Management of Sable Island; Canadian Wildlife Service, Sackville, New Brunswick, 85 pp. 